University of Rhode Island

DigitalCommons@URI

Open Access Master's Theses

1987

\title{
Influence of Tillage Systems and Winter Cover on Off-Site Losses of Sediment, Nutrients and Atrazine in Silage Corn Production
}

\author{
William R. Arcieri \\ University of Rhode Island
}

Follow this and additional works at: https://digitalcommons.uri.edu/theses

\section{Recommended Citation}

Arcieri, William R., "Influence of Tillage Systems and Winter Cover on Off-Site Losses of Sediment, Nutrients and Atrazine in Silage Corn Production" (1987). Open Access Master's Theses. Paper 1382. https://digitalcommons.uri.edu/theses/1382 in Open Access Master's Theses by an authorized administrator of DigitalCommons@URI. For more information, please contact digitalcommons-group@uri.edu. 
INFLUENCE OF TILLAGE SYSTEMS AND WINTER COVER ON OFF-SITE LOSSES OF SEDIMENT, NUTRIENTS AND ATRAZINE IN SILAGE CORN PRODUCTION

BY

WILLIAM R. ARCIERI

A THESIS SUBMITTED IN PARTIAL FULFILLMENT OF THE REQUIREMENTS FOR THE DEGREE OF

MASTER OF SCIENCE

IN

NATURAL RESOURCES SCIENCE 


\section{MASTER OF SCIENCE THESIS \\ OF}

WILLIAM R. ARCIERI

APPROVED:

Thesis Committee

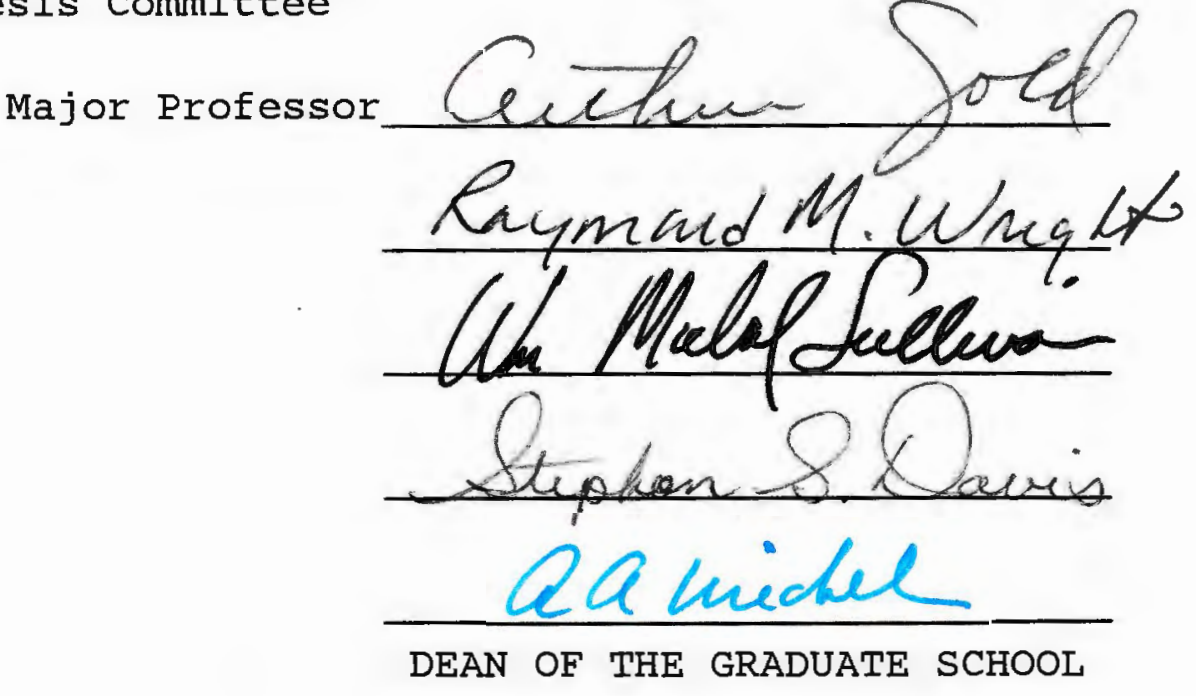




\section{ABSTRACT}

Nonpoint source pollution has been recognized as a primary cause of water pollution in the United states. Agricultural activities have been cited as the leading contributor of nonpoint source pollutants. Runoff and eroded sediment are the primary transport agents for agrichemical losses from agricultural fields. Conservation tillage has been promoted over the past two decades as a cost-effective agronomic practice that can reduce runoff and erosion from agricultural fields.

The goal of this study was to compare the edge-of-field losses of waterborne substances from conservation tillage and conventional tilage plots both with and without the use of a winter cover crop under the corn-for-silage management program. Corn for silage is a prevailing practice in New England and comprises about 20 percent of the total acres harvested.

Twelve field plots measuring 3.4 meters wide by 22.1 meters long with a 2.5 percent slope were equipped with an overland flow collection system. Runoff was monitored during the 1985 and 1986 growing seasons (June through November). Runoff samples were analyzed for sediment, nitrogen, and atrazine content.

Runoff occurred on 22 out of 51 rainfall events that occurred during the study period. In all treatments, 57 to 62 percent and 70 to 77 percent of the runoff and soil 
loss, respectively, were associated with excessive rate storms. Runoff and soil loss were considerably higher on plots with less than 30 percent residue cover. Surface residue from the winter cover crop reduced runoff and soil loss by 29 and 54 percent, respectively, compared to plots without the winter cover crop.

Total nitrogen losses through overland flow during the 1986 growing season ranged from 0.33 to $3.42 \mathrm{~kg} / \mathrm{ha}$ or 0.1 to 1.3 percent of the applied nitrogen. Nitrogen losses were highest on plots without a winter cover crop. Total Kjeldahl nitrogen accounted for 89.5 to 94 percent of the total nitrogen loss. The greatest losses of total Kjeldahl nitrogen were associated with the events that had the greatest sediment movement.

Total atrazine losses through overland flow was less than 0.5 percent of that applied for all treatments. Atrazine losses were 74 percent lower in conservation tillage systems than in tillage systems with less than 30 percent residue cover. Tillage method had no significant effect on flow weighted atrazine concentrations in runoff.

The hydrology component of the CREAMS computer model predicted runoff closest to the observed runoff values using the breakpoint method in the conventional system and the curve number method in the notill system. The breakpoint method performed better than the curve number method for small intense, storms. In order to obtain close agreement between predicted and observed runoff values, recommended 
parameter values describing soil properties were adjusted to reflect lower infiltration rates. 


\section{ACKNOWLEDGEMENTS}

I am sincerely grateful to my major professor, Dr. Arthur J. Gold, for his constant support and guidance throughout my graduate program. I also greatly appreciate the helpful comments that were provided by Dr. W. Michael Sullivan, Dr. Raymond Wright, and Steve Davis during the preparation of this thesis. Appreciation is also extended to Dr. Conrad Skogley who chaired my defense.

Special thanks are extended to Joseph McClory for his efforts and cooperation with the laboratory analysis, william R. DeRagon for his help with computer graphics and statistical analysis, Frank Postma for his assistance with the CREAMS model, and Mary Salerno for her superior typing of this manuscript. I would also like to thank Bethany Eisenberg and Bonnie Lamb for their friendship and support.

Finally, I am especially grateful to my wife, Elizabeth, for her encouragement, patience, and faith that has made this endeavor possible: 
CHAPTER

$\underline{\text { PAGE }}$

ABSTRACT • • • • • • • • • • • • • • • • • • • • • • i

ACKNOWLEDGMENTS • - • • • • • • • • • • • • • • • • V

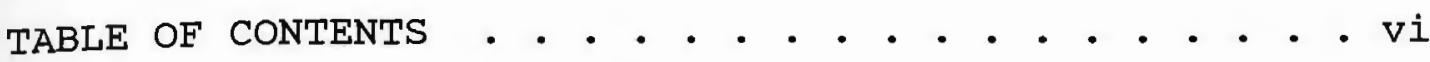

LIST OF TABLES • • • • • • • • • • • • • • • • • • • viii

LIST OF FIGURES • • • • • • • • • • • • • • • • • • . ix

1. INTRODUCTION • . . . . . . . . . . . . . . . 1

1.1 Background . . . . . . . . . . . . . 1

1.2 Specific objectives . . . . . . . . . 5

2. LITERATURE REVIEW • . • • • • . • • • . • . . 6

2.1 Effect of Conservation Tillage

on Runoff and Erosion . . . . . . . . 6

2.2 Runoff and Sediment as Transport Agents . . 8

2.3 Iosses of Nitrogen from Agricultural Land . 10

2.4 Water Quality Impacts of Nitrogen Losses • 11

2.5 Influence of Tillage on Nitrogen Losses . . 11

2.6 Atrazine Background . . . . . . . . . 13

2.7 Atrazine Toxicity . . . . . . . . . . 14

2.8 Behavior and Persistence of Atrazine

in the Environment . . . . . . . . 15

2.9 Atrazine Losses from Cropland . . . . . . 16

2.10 Influence of Tillage on

Atrazine Losses . . . . . . . . . . 17

3. METHODS • . . . . . . . . . . . . . . . . 20

3.1 Site and Treatment Descriptions . . . . . 20 
3.2 Monitoring Approach . . . . . . . . 22

3.3 Laboratory Procedure . . . . . . . 26

4. RESULTS OF RUNOFF AND SOIL LOSS . . . . . . 29

4.1 Rainfall . . . . . . . . . . . 29

4.2 Runoff ................ 31

4.3 Soil Loss . . . . . . . . . . . . 39

4.4 Event-based Analysis . . . . . . . . 46

5. AGRICHEMICAL LOSSES ............ . . 50

5.1 Nitrogen Loss in Runoff . . . . . . . 50

5.2 Nitrogen Concentrations in Runoff . . . . 53

5.3 Atrazine Concentrations in Runoff . . . . 56

5.4 Atrazine Loss in Runoff . . . . . . . 58

6. PERFORMANCE ASSESSMENT OF THE CREAMS

HYDROLOGY COMPONENT . . . . . . . . . . 62

6.1 Modeling Approach . . . . . . . . 62

6.2 Hydrology Component Description ...... 65

6.3 Model Performance Assessment . . . . . 67

7. CONCLUSIONS . . . . . . . . . . . . 82

8. RECOMMENDATIONS .............. 84

LITERATURE CITED . . . . . . . . . . . 85 
1. Agronomic Activity . . . . . . . . . .

2. Comparison of Monthly Precipitation to Monthly Means of the 22 Year Rainfall Record ................ 30

3. Hydrological Summary . . . . . . . . 32

4. Surface Residue after Tillage . . . . . 35

5. Soil Loss Summary . . . . . . . . . 40

6. Mean Sediment Concentration ........ 45

7. Average Nitrogen Loading . . . . . . . . 51

8. Flow-weighted Mean Nitrate Concentration . . 54

9. Flow-weighted Mean TKN Concentration . . . . 55

10. Flow-weighted Mean Concentrations of Atrazine in Runoff . . . . . . . . . . 57

11. Atrazine Loss in Runoff . . . . . . . . 59

12. Recommended and Best-fit Parameter Values used for the Hydrology Component of the CREAMS Model ............... .

13. Statistical Summary of the Hydrology Component Assessment-No-till with Rye Cover . . . . . . . . . . . . . .

14. Statistical Summary of the Hydrology Component Assessment-Conventional Tillage .

15. Comparison of Observed and Predicted Runoff for Conventional Tillage using Best-fit Parameter Values . . . . . 78

16. Comparison of Observed and Predicted Runoff for No-till with Rye Cover using Best-fit Parameter Values . . . . . . . . 


\section{IIST OF FIGURES}

EIGURE

$\underline{\text { PAGE }}$

1. Schematic diagram of the overland flow collection system . . . . . . . . 24

2. Cumulative distribution functions showing the frequency of events that the given runoff depth was exceeded . . . 38

3. Cumulative distribution functions showing the frequency of events that the given soil loss value was exceeded . . 43

4. Predicted versus observed runoff values for conventional treatment with corresponding linear regression lines plotted against a 1:1 line . . . . . . 74

5. Predicted versus observed runoff values for no-till with rye cover treatment with corresponding linear regression lines plotted against a 1:1 line 
CHAPTER 1

INTRODUCTION

\subsection{Background}

Nonpoint source pollution is among the nation's most serious natural resource problems. In almost every state, nonpoint source pollution has been recognized as a primary cause of water pollution (Assoc. of State and Interstate Water Pollution Control Administrators, 1984). Since passage of the Federal Water Pollution Control Act Amendments of 1972 (FWPCA, PL 92-500) tremendous progress, through technological advances, has been made in reducing and treating point sources of pollution (i.e. wastewater treatment plant outflows). However, because of the diffuse and intermittent nature of nonpoint source pollution, there has only been limited success in devising and implementing effective methods of control (Vigon; 1985).

Agricultural activities have been cited as the leading contributor of nonpoint source pollutants in United States. According to the 1977 National water guality Inventory (USEPA, 1978), surface water quality was affected by agricultural nonpoint pollution in 68 percent of the drainage basins throughout the country. Another study conducted by Resources for the Future, Inc. concluded that about 66 percent of the suspended solids loading in our nation's rivers is attributed to agricultural sources 
(Duda, 1985). The Conservation Foundation estimates that agricultural sources contribute about 70 percent of the 4.5 billion tons of soil loss estimated to occur each year throughout the country (Clark, 1983).

Along with soil erosion, the increasing use of pesticides and fertilizers poses a major threat to the quality of surface waters and drinking water supplies. The use of commercial nitrogenous fertilizers has increased Five-fold from 2,400,000 metric tons in 1960 to $11,300,000$ metric tons in 1980 (Ritter, 1986). In 1980 about 300,000 tons of pesticides were used in agriculture. Pesticide use is projected to exceed 1 million tons by the end of the decade (Chesters and Schierow, 1985).

Considering that 63 percent of all nonfederal land in the United States is used for agricultural purposes (USDA, 1981), it is not surprising that agricultural activities have been cited as a major source of nonpoint source pollution. Best management practices designed to reduce soil erosion and agrichemical losses from croplands could lead to substantial improvements in the quality of surface water downstream from agricultural land.

Conservation tillage has been promoted over the past two decades as a cost-effective agronomic practice that can reduce overland flow and erosion. Conservation tillage, as defined by the Soil Conservation Service, is any form of tillage that leaves at least 30 percent of the soil surface covered with crop residue after planting (SCSA, 1982). 
Conservation tillage practices range from notill farming, where planting occurs in the undisturbed residue of the previous crop, to modified tillage practices such as chisel plowing, disking, or ridge planting. The conventional moldboard plow buries at least 95 percent of the surface residue, leaving the bare soil exposed to erosive elements. The common element in all conservation tillage practices is that soil disturbance is reduced and an appreciable amount of crop residue is left at the surface. This additional residue on the soil surface has been shown to be very effective in reducing soil detachment and sediment loss.

The goal of this study was to compare the edge-of-field losses of waterborne substances from conservaton and conventionally tilled plots both with and without the use of a winter cover crop under the corn-for-silage management program. To accomplish this goal a replicated field study of overland flow from natural rainstorms was conducted. Corn harvested as silage is a principal crop in New England and constitutes about 20 percent of the total harvested acres. Corn harvested for silage leaves relatively small amounts of crop residue on the surface after harvest (McGregor and Greer, 1982; Wendt and Burwell, 1985). High erosion rates have been observed when insufficient plant residue has been left on the soil surface (Laflen and Colvin, 1981; Wendt and Burwell, 1985; Kenimer et al. 1986). The combination of the inadequate amounts of surface residue and the fact that a major portion of the farming in New 
England is done on highly erodible silt loam soils creates a situation where high concentrations of eroded sediment and agrichemicals, suspended in the runoff, may be discharged directly into adjacent water bodies.

Field studies can provide useful information in regards to evaluating the effects of different management systems on pollutant export or delivery. However, the measured data is limited to site specific conditions and local weather patterns. National conservation agencies have recently focused on developing reliable, predictive models that can be used to evaluate management practices by incorporating long-term weather data and a variety of site conditions.

The U.S. Department of Agriculture-Agricultural Research Service developed a computer model entitled, Chemicals, Runoff and Erosion, in Agricultural Management Systems, more commonly known as the CREAMS computer model (Knisle, 1980). The CREAMS model was developed specifically to evaluate the effects of alternate management systems on edge-of-field losses of sediment, nutrients, and pesticides through overland flow. The model is segmented into four seperate components (i.e. hydrology, erosion, pesticides, nutrients). The data generated from the hydrology component is used to drive the complex calculations of the other three components. Therefore, the performance of the CREAMS model in predicting sediment and agrichemical losses is highly dependent upon the capability of the hydrology component to simulate processes that affect the magnitude and the 
occurrence of overland flow. The intent of the present study is to evaluate the predictive capabilities of the hydrology component by comparing the observed runoff values to the predicted runoff values. 1.2 Specific Objectives:

1) Quantify the offsite soil and water losses in relation to surface residue cover and tillage differences in the corn-for-silage environment.

2) Evaluate the atrazine and nitrogen content in runoff from the various tillage/residue treatments.

3) Compare observed runoff values to predicted runoff values using the hydrology component of the CREAMS computer model. 
CHAPTER 2

LITERATURE REVIEW

2.1 Effects of Conservation Tillage on Runoff and Erosion

Since the early 1970 's, considerable research has been conducted on conservation tillage to determine its effect on reducing runoff and erosion from agricultural fields. Most of the research has demonstrated that conservation tillage can effectively reduce sediment loss relative to the conventional moldboard plow system by 50 to 90 percent (Moldenhauer et al., 1983; Burwell and Kramer, 1983; McDowell and McGregor, 1984; Wendt and Burwell, 1985). The substantial reduction in sediment loss has been mainly attributed to the ability of the surface residue to dissipate rainfall energy and, thereby, reduce soil particle detachment. Wischmeier and Smith (1978) computed that a soil surface covered with residue at rates of 20,40 , and 60 percent cover will receive 65, 35, and 25 percent, respectively, of the rainfall erosivity striking bare ground. Laflen and Colvin (1981) reported erosion to be an inverse, exponential function of percent residue cover.

The reduced sediment loss observed from conservation tillage systems can also be attributed to surface residue affects on runoff velocity. Niebling and Foster (1977) reported that runoff velocity decreased with increasing levels of residue. Partially incorporated corn stalk 
residue at $2 \mathrm{Mg} / \mathrm{ha}, 4 \mathrm{Mg} / \mathrm{ha}$, and $5 \mathrm{Mg} / \mathrm{ha}$ levels of cover decreased runoff velocity by 10,30 , and 40 percent, respectively, compared to bare soil. A decrease in runoff velocity reduces the transport capacity and the detachment energy of overland flow.

The effect of conservation tillage on reducing runoff volumes has been found to be less dramatic and quite variable. In the previously cited studies, where erosion had been reduced by 50 to 90 percent, runoff volumes decreased by only 13 to 50 percent compared to that observed from the conventioanl moldboard plow system. Several researchers have reported that runoff volumes in the no-till systems are comparable to that observed in the moldboard plow system (Siemens and Oschwald, 1976; Mannering et al., 1966; Lindstrom et al. 1981; Laflen and Colvin, 1981).

For most of the reported studies, the chisel plow apparently seems more effective in reducing runoff than no-till but is not as effective as no-till in reducing erosion. Lindstrom and Onstad (1984) reported that even though the surface residue found in conservation tillage systems reduced the impact of weathering forces that cause surface sealing, a relatively impervious surface layer can develop in the absence of tillage. The higher erosion and decreased runoff observed in the chisel plow systems is most likely attributable to greater soil detachment and higher infiltration rates resulting from the tillage operations. In the no-till systems, surface sealing conditions are likely 
to develop due to the lack of tillage. As a result, soil detachment and infiltration rates are likely to be considerably lower. Lindstrom et al. (1981) characterized the soil surface under the no-till systems as having a lower volume of macropores, reduced saturated hydraulic conductivity, and reduced infiltration cababilities.

\subsection{Runoff and Sediment as Transport Agents}

Waterborne pesticides and nutrients can leave a field either in solution, adsorbed to sediment particles, or as solids. Soluble nutrients and pesticides move rapidly and are more mobile than solids or sediment-associated substances which are subject to the processes of erosion and sedimentation.

The partitioning between the sediment-adsorbed phase and the dissolved phase for any compound has been cited as the single most important factor in determining the fate of pesticides and nutrients in the field Helling (1970). Adsorption or the adhesion of a substance to a soil particle is often described by the adsorption partition coefficient Ks, (Steenhuis and Walter, 1979). Ks is defined as the ratio of the concentration of the substance adsorbed to sediment divided by the concentration of the substance in solution. Substances with a high Ks value (>1000) such as organic nitrogen, ammonium nitrogen, solid phase phosphorous, and paraquat will move with the soil. Atrazine, a moderately adsorbed pesticide with a Ks value of 
about five, will move in solution and adsorb to sediment. Nitrate nitrogen has a very low Ks value (0.05) and moves primarily in solution.

For substances moderately or weakly adsorbed to sediment, the highest concentrations in runoff have been found in runoff events occurring close to the time of application (Hall et al., 1972; Smith et al., 1974). Baker and Johnson (1979) found that alachlor and cynazine, herbicides transported primarily with water, were present in runoff occurring soon after application but concentrations rapidly declined in later runoff events.

Studies have demonstrated that chemicals which move adsorbed to sediments may have higher concentrations in the eroded material compared to the soil from which it originated. Massey et al. (1952) reported that eroded soil material contained 3.4 times as much available-P as the in situ soil. The authors also found that the enrichment of the eroded soil was inversely proportional to sediment concentration and net sediment loss. This relationship was also observed in another study done by stoltenberg and White (1953). At sediment concentrations of $40,000,2,700$, and 440 milligrams per liter, the ratio of the nitrogen content on the eroded sediment to the in situ soil increased from 1.3 to 2.0 to 5.0 times, respectively. The authors found that through the selective erosion process, an increasing proportion of finer soil particles and organic matter were present in the runoff as the transport energy decreased. The 
lighter clay and organic matter particles were not as subject to deposition. Once suspended, these particles with their adsorbed substances were able to leave the field more readily than larger, heavier particles. The clay and organic matter particles have higher cation exchange capacities than the coarser particles and, therefore, can adsorb greater amounts of nutrients.

\subsection{Losses of Nitrogen from Agricultural Land}

Researchers have found significant nitrogen losses associated with agricultral activity. Smolen (1981) monitored nutrient runoff from agricultural and non-agricultural watersheds for four years and reported that there was a 1.5 to two-fold increase in nitrogen concentration attributable to agricultural land use. Timmons et al. (1968) found $\mathrm{N}$ losses as high as $14.5 \mathrm{~kg} / \mathrm{ha}$ per year from corn-cropped plots. In contrast, forested areas have been reported to have nitrogen losses ranging from less than 1 to $3.36 \mathrm{~kg} / \mathrm{ha}$ (Frink, 1967).

In most cases, nitrogen leaving agricultural fields by surface runoff is in the organic-N form associated with eroded soil (Armstrong et al., 1974). Nitrate-N, the major anionic form of nitrogen, will normally be assimilated by plant roots or leach through the soil profile to the groundwater (Keaney, 1973). Losses of nitrate through overland flow are generally associated with storms occurring 
immediately after fertilization or the leaching of nutrients from surface residue (Timmons et al., 1970).

\subsection{Water Quality Impacts of Nitrogen Losses}

Excessive offsite losses of nitrogen from fertilized agricultural fields can have substantial adverse effects on water quality. High nitrate concentrations in drinking water can cause methemoglobinemia ("Blue Baby syndrome") in infants during the first six months of life (National Reaearch Council, 1978). The drinking water standard for nitrate-N concentration is set at $10 \mathrm{mg} / 1$ by the Environmental Protection Agency to safeguard against methemoglobinemia in infants (Safe Drinking Act U.S.P.L. 93-523). In brackish and salt water systems, increased nitrogen inputs into surface waters could promote excessive eutrophication (Ryther and Dunstan, 1971; Harlin and Thorne-Miller, 1981). Nitrogen, as ammonia, can also be acutely toxic to fish. The current water quality standard for unionized $\mathrm{NH}_{3}$, which is the form toxic to fish, is 0.02 $\mathrm{mg} / \mathrm{l}$. At common temperatures and near neutral $\mathrm{pH}, 2 \mathrm{mg} / \mathrm{l}$ of $\mathrm{NH}_{4}-\mathrm{N}$ results in a $\mathrm{NH}_{3}$ concentration of about $0.02 \mathrm{mg} / 1$, thus the $2 \mathrm{mg} / \mathrm{l}$ value for $\mathrm{NH}_{4}-\mathrm{N}$ is often quoted as a level of concern (U.S.EPA, 1976).

\subsection{Influence of Tillage on Nitrogen Losses}

Research has shown that concentrations of both soluble nitrogen (mg/l) and sediment-adsorbed nitrogen (mg/kg) are 
generally higher in the runoff from conservation tillage systems compared to the runoff from conventional plowed systems. However, total nitrogen loss depends primarily on the runoff volume and the sediment load generated from these systems.

Romkens et al. (1973) reported a curvilinear relationship between soil loss and the loss of sediment-associated nitrogen. Conventional tillage had the highest loss of sediment- $N$ even though conservation tillage systems with less soil loss had relatively higher concentrations of sediment-N. Differences in the nitrogen concentration in runoff sediment between tillage systems are primarily due to selective soil erosion processes. The authors also noted that the proportion of nitrogen that is organic, as well as the total nitrogen content of sediment, increased with the degree of erosion selectivity.

Baker and Laflen (1982) observed higher concentrations of nitrate-N in runoff from conservation tillage plots than from conventionally-tilied plots. However, conservation tillage plots lost less than one-half of the total loading of nitrate-N that was lost from the conventional plots. The difference in loading was the result of runoff from conventional plots being 3.3 times that of conservation tillage plots.

Baker and Laflen (1982) found that increasing surface residue on the soil surface decreased the volume of runoff 
and, in turn, decreased nutrient losses by up to 80 percent for plots with the greatest residue amounts.

McDowell and McGregor (1980) reported that both the percentage of the total nitrogen and the concentrations of nitrate-N transported in solution from conservation tillage was significantly greater than in conventional tillage systems. In conventional-till corn for grain only 9 percent of the total nitrogen was transported in solution in runoff compared to 40 percent in the no-till plots. However, conservation tillage systems reduced total nitrogen losses (solution and sediment) relative to that of conventional tillage because of the significant reduction in soil loss. Soil loss was reduced by more than 92 percent in reduced tillage and notill systems. The total loss of nitrogen was reduced by more than 70 percent compared to that in conventional tillage.

Increased concentrations of nitrate-N in the runoff from conservation tillage systems have been attributed to the combined effects of leaching of nitrogen from the surface residue, decreased fertilizer incorporation, and the enrichment of sediment as a result of selective erosion processes(Johnson et al., 1979; McDowell and McGregor, 1984; Timmons et al., 1970).

\subsection{Atrazine Background}

Atrazine (2-chloro-4-ethylamino-6-isopropylaminos-triazine) was introduced into the market in 1953 by the 
CIBA-Giegy Corp. of Ardsley, New York. Atrazine accounts for nearly one half of the herbicides used in corn production and was identified in 1971 as the most heavily used herbicide in the United States (Shoemaker and Harris, 1979 ) .

Atrazine is an effective photosynthetic electron inhibitor in broadleaf and some grassy weeds. Corn has the ability to rapidly metabolize and, therefore, detoxify atrazine (Knisle, 1970). Its high degree of selectivity allows for applications to the soil before and after the emergence of the crop and greatly reduces the need for time consuming tillage operations.

\section{$\underline{2.7}$ Atrazine Toxicity}

Direct toxicity of atrazine to fish is fairly low, with a reported 96 hour $L_{5} C_{50}$ for rainbow trout of $4.5 \mathrm{mg} / \mathrm{l}$ (Smith, 1982). Atrazine has been implicated in the widespread decline of submerged vascular plants in the Chesapeake Bay (Wu, 1977). In a microcosm bioassay, the authors found that exposure of Vallisneria americana (Water Celery) to $0.12 \mathrm{mg} / 1$ atrazine for 30 days resulted in 100 percent mortality. Exposure of the plants to $0.012 \mathrm{mg} / \mathrm{l}$ atrazine resulted in 50 percent mortality after 47 days, along with inhibition of growth and reproduction. In experimental ponds, DeNoyelles et al. (1982), observed inhibition of algal photosynthesis at 0.2 to $5.0 \mathrm{mg} / \mathrm{l}$ ambient atrazine levels, with observable effects at 
concentrations as low as $1 \mathrm{ug} / 1$ in laboratory bioassays. In 1977, the National Research Institute suggested that the "no-adverse" effect level for atrazine is about $180 \mathrm{ppm}$.

2.8 Behavior and Persistence of Atrazine in the Environment Atrazine shows moderate adsorption characteristics with reported Ks values ranging from 1 to 8 depending on the soil type and the amount of cations present (Cohen et al., 1984). Helling (1970) in his classification system of pesticide mobility in the environment, characterized atrazine as having intermediate mobility. Atrazine has a solubility of $33 \mathrm{mg} / \mathrm{l}$ in water and will exist in both adsorbed and dissolved states in the soil environment (Colbert et al., 1975). Atrazine has been found to have a half-life of less than one month but it can persist in the soil up to 18 months (Wauchope, 1978). Persistence tends to be greater at lower soil depths and longer in northern latitudes (Kaufman and Kearney, 1970).

Wauchope (1978) stated that atrazine had an apparent "runoff-available" half-life of 7 to 10 days, based on the fact that the surface applied herbicide was subject to volatilization, photodegradation, and leaching. Hall et al. (1972) found that at the recommended application rate of $2.24 \mathrm{~kg} / \mathrm{ha}, 60$ percent of the applied atrazine was lost from the soil through degradation after 1 month, and 91 percent was lost after 4 months. Sirons et al. (1973) found that 
about 15 percent of the applied atrazine remained after 2 weeks and after 52 weeks less than 10 percent remained.

\subsection{Atrazine Losses from Cropland}

A number of studies have shown that concentrations and losses of surface applied atrazine are highest when intense rainfall occurs immediately after herbicide application. In a rainfali simulation study, when rainfall was applied one hour after atrazine application, runoff samples collected at the onset of runoff had atrazine concentrations as high as $10.34 \mathrm{ppm}$ but runoff samples collected at the end of the storm had concentratios as low as $0.34 \mathrm{ppm}$ (White et al., 1967). Concentrations were 50 percent lower when the storm occurred 96 hours after application.

Bailey et al. (1974) measured atrazine losses in runoff from a 100-year storm occurring one hour after application from bare soil plots with atrazine applied at two different rates. Losses from plots treated with $3.36 \mathrm{~kg} / \mathrm{ha}$ of atrazine were 10 to 13 percent of that applied and losses from plots treated with $1.68 \mathrm{~kg} / \mathrm{ha}$ of atrazine were 6.5 to 12.5 percent of that applied.

Under natural rainfall conditions, Hall (1974) observed runoff losses to be 5 percent of that applied when the first runoff event occurred 6 days after an atrazine application $2.2 \mathrm{~kg} / \mathrm{ha}$. Atrazine concentrations were highest in the first two runoff events following application and 87 to 93 percent of the total atrazine loss occurred in the first 
five runoff events occurring in the month following application. Baker and Johnson (1979) found that seasonal losses were less than five percent in years when the first runoff producing storms occurred two weeks or more after application. However, in one year in which a storm took place 24 hours after application, the losses were 16 percent of the applied atrazine.

Although the results of these studies vary in terms of the quantities of atrazine lost in runoff, they all have demonstrated that atrazine concentrations are much higher in the sediment portion of the runoff. Baker and Johnson (1979) found atrazine concentrations in eroded sediment were five times as large as those in the runoff water, but more atrazine was lost with the water portion of runoff because the volume of water lost was much higher than sediment lost. Hall (1974) reported atrazine concentrations to be about 2.5 times higher on sediment than in water but nearly 90 percent of the atrazine loss was in the dissolved phase. Bailey et al. (1974) also found that 70 to 80 percent of the atrazine loss was in the dissolved phase.

\subsection{Influence of Tillage on Atrazine Losses}

Researchers that have investigated the effects of conservation tillage on the losses of atrazine in runoff have had contradictory results. Concentrations of atrazine in the runoff and in the eroded sediment are generally higher in conservation tillage systems than in conventional 
tillage systems. However, the total waterborne losses of atrazine is dependent upon the effect of conservation tillage on total runoff and soil loss. Smith et al. (1974) reported substantially greater losses of atrazine from no-till plots than from conventional plots. For one storm, the maximum atrazine concentration in runoff was $0.87 \mathrm{ppm}$ and total loss was $28.9 \mathrm{~g} / \mathrm{ha}$ from conventional plots, while no-till plots had a maximum concentration of $1.7 \mathrm{ppm}$ and a total loss of $108.8 \mathrm{~g} / \mathrm{ha}$. For another storm, the conventional plots lost $3.1 \mathrm{~g} / \mathrm{ha}$ of atrazine, while the no-till plots lost $127.7 \mathrm{~g} / \mathrm{ha}$. The authors attributed this trend to the increased runoff volume observed in the no-till plots.

Schwab et al. (1975) also reported high atrazine concentrations and losses in surface runoff from notill corn plots, compared to conventional tillage. Mean runoff concentrations were $105 \mathrm{ppb}$ in the conventional plots and $174 \mathrm{ppb}$ in the notill plots. Total atrazine losses in surface runoff were 8.5 percent of that applied for conventional tillage and 12.5 percent for no-till plots.

Baker et al. (1982) investigated the effects of different levels of residue cover on atrazine loss. Atrazine concentrations in runoff were inversely related the amount of residue cover. With no residue cover, atrazine concentrations in runoff were $141 \mathrm{ppb}$ in the runoff water and $1110 \mathrm{ppb}$ in the sediment. At the $1500 \mathrm{~kg} / \mathrm{ha}$ level of residue cover water and sediment concentrations were $88 \mathrm{ppb}$ 
and $710 \mathrm{ppb}$, respectively. However, the total atrazine loss exponentially decreased with increasing residue cover. The authors attributed the decrease in atrazine loss to the decreased soil loss and decreased runoff volume in the higher residue plots. 
CHAPTER 3

METHODS

3.1 Site and Treatment Descriptions

The study was initiated in June, 1985 on 12 field plots located at the Plains Field Laboratory of the Rhode Island Agricultural Experiment Station. Each plot measured 3.4 meters wide by 22.1 meters long with a slope of 2 to 3 percent. All plots were surveyed with a level to insure that there was no cross slope. The soil is an Enfield silt loam (coarse-silty over sandy-skeletal, mixed, mesic, Typic Dystrochrept) consisting of well drained loamy soils with a silt mantle formed in glacial outwash.

Three different tillage systems (conventional, chisel, no-till) were studied. Conventional tillage included moldboard plowing in the spring at a depth of $20 \mathrm{~cm}$, followed by two passes with an offset disc and a finishing harrow. The chisel plow used has straight knives spaced $0.7 \mathrm{~m}$ apart and limits soil disturbance to 35 to 40 percent of the area. No other cultivations were performed after seedbed preparation or on the no-till plots. Tillage operations were done at 45 degrees from the contour. Corn (Zea mays CV. Agway $310 \mathrm{x}$ ) was seeded on all plots with a modified John Deere Max-Emerge ${ }^{R}$ no-till planter. The sequence of agronomic activity is presented in Table 1. A winter cover crop of rye (Secale cereale L.) was 
Table 1. Agronomic Activity

Seed Bed Preparation

June 7

June 11

Atrazine Application

(1.1 kg/ha a.i. Aatrex 4L)

Fertilizer Application

Sidedress ( $30 \mathrm{~kg} / \mathrm{ha}$ )

Broadcast $(250 \mathrm{~kg} / \mathrm{ha})$

Harvest

Rye Seeded
June 11

July 23

Oct. 16

Oct. 22
May 30

May 31

May 31

July 11-16

Sept. 22

Sept. 26 
planted on six plots immediately after the silage harvest to establish residue cover during the dormant season. The three tillage systems were established on plots with and without the winter cover crop and each of the six different treatments are replicated on two runoff plots. Estimates of percent cover were made immediately after tillage in both seasons by the line transect method as described by sloneker and Moldenhauer (1977). Estimates of the total residue cover $(\mathrm{kg} / \mathrm{ha})$ were obtained by removing all the visible residue contained in 0.01 square meter. Three samples were taken from each plot and were oven-dried $\left(60^{\circ} \mathrm{C}\right)$ for a week before weighing.

\subsection{Monitoring Approach}

The surface water collection system for each plot consisted of a concrete apron, $0.6 \mathrm{~m}$ wide by $3.4 \mathrm{~m}$ long, at the base of slope (to prevent erosional scouring) attached to $30.5 \mathrm{~cm}$ wide and $15 \mathrm{~cm}$ deep aluminum trough (Figure 3 ). Surface runoff on each plot was hydrologically isolated by aluminum barriers extending approximately $20 \mathrm{~cm}$ above and $10 \mathrm{~cm}$ below the surface. Runoff was directed through a PVC flow splitter (Reese et al., 1982) designed to divert 10 percent of the total runoff into a calibrated 230 liter collection tank. The rest of the runoff was directed to a retention basin. The twelve splitters were calibrated with three replications of equal volumes of water at varying flow 
Figure 1. Schematic diagram of the overland flow collection system. 


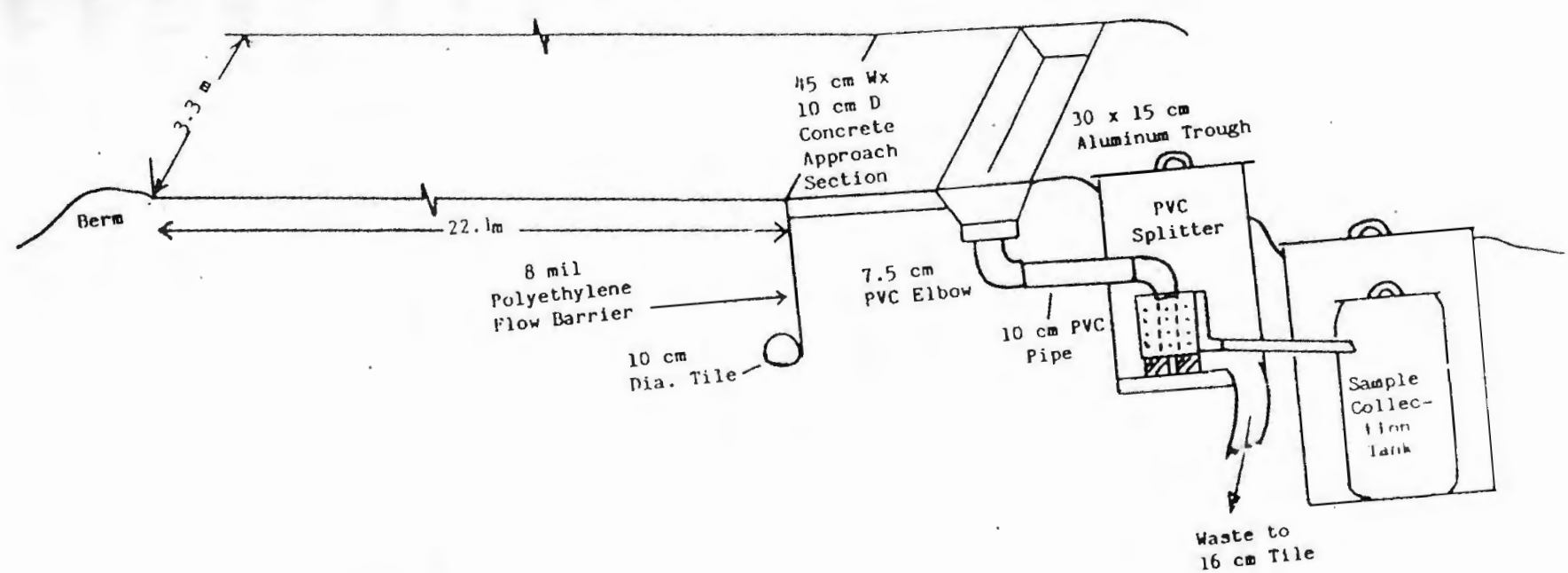

OYRDANO FLOY COLACTION SYSTEM 
rates. Mean volume collected was 9.75 percent with a standard deviation of 1.47 .

As specified by the Field Manual for Research in Agricultural Hydrology (Brakensiek et al., 1979), the collection system can was designed for a maximum runoff rate from a 10 year, 5 minute rainstorm ( $41 \mathrm{~L} / \mathrm{sec})$ with no infiltration (Hershfield, 1975). The storage capacity was designed to accomodate the runoff volume predicted by the SCS curve number method for a 5 year 24 hour storm (Mockus, 1964). Runoff and soil loss was monitored for two growing seasons (1985 and 1986) from the time of pesticide application to several weeks after the establishment of the winter cover (June through November). The depth of water in the collection tank was measured after each runoff event for runoff volume calculations. Runoff volume generated from precipitation falling directly on the concrete was calculated and then subtracted from the total volume.

A two liter aliquot sample was obtained from each collection tank with a manual pump after the sediment was thoroughly suspended by mixing. A $250 \mathrm{ml}$ subsample was vacuum filtered [Whatman 4] to separate sediment from solution. The sediment was dried overnight at $105^{\circ} \mathrm{C}$ and weighed to determine sediment concentration. The filtrate was frozen and subsequently analyzed for nitrate concentration. The remainder of the two liter aliquot 
sample was stored at $4^{\circ} \mathrm{C}$ until the sample was analyzed for atrazine and organic nitrogen (TKN) concentrations.

\subsection{Laboratory Procedure}

Runoff samples (unfiltered) were analyzed for total Kjeldahl nitrogen (TKN) content by using block digestion, colorimetric method (EPA Method 351.2). This procedure, as described by Eastin (1978), measured the sum of the free-ammonia and organic nitrogen compounds in solution and adsorbed to sediments.

In 1985, the block digestor was not equipped with an automatic temperature regulator and temperature settings were not consistent for each analysis. Problems were also encountered in the colorimetric procedure due to the high acidity of the samples. There was substantial variation between duplicate samples and the percent recovery of the standards were poor. Therefore, the nitrogen data generated with 1985 runoff samples was considered inadequate and was not used in the analysis of nitrogen losses.

In 1986, an automatic temperature regulator was installed on the block digestor and the problems with the colorimetric procedure were corrected by diluting the samples with sodium hydroxide. Recovery of synthetic standards used with the 1986 runoff samples ranged from 95 to 105 percent. Variation between duplicate samples was within 10 percent. 
Nitrate concentrations in filtered runoff samples were measured using a Technicon Auto Analyzer equipped with a phototube colorimeter (EPA Method 353.2). The automated, cadmium reduction method for nitatre analysis is further described by Henrikson and Selmer-Olsen, (1970). To insure quality control, duplicate samples and standards of nitrate-N were routinely analyzed.

A $200 \mathrm{ml}$ aliquot of runoff was filtered through glass microfiber filters [Whatman (GC/FA)]. The atrazine in the filtrate was extracted twice with $25 \mathrm{ml}$ of dichloromethane. The extracts were then dried over anhydrous sodium sulphate overnight and concentrated to $1 \mathrm{ml}$ with a Kuderna-Danish apparatus. The dichloromethane was then removed from the concentrated extracts by adding hexane and submersing the samples an a water bath $\left(60^{\circ} \mathrm{C}\right)$ for 30 minutes. The extracts were then diluted to a $5 \mathrm{ml}$ volume with hexane and transfered to glass vials.

The solution was then injected into a Shimadzu 6 AM gas chromatograph equipped with a nickel 63 electron capture detector for atrazine analysis. The glass columns $12.5 \mathrm{~m}$ long by $3 \mathrm{~mm}$ i.d.) were packed with 1.5 percent ov-17 and 1.95 percent ov-210 on 80/100 mesh supelco support. The flow rate of 5 percent methane/argon 99.999 percent purity carrier gas was $40 \mathrm{ml} / \mathrm{min}$. Operating temperature for the injection port and detector was $220^{\circ} \mathrm{C}$ and the column was maintained at $180^{\circ} \mathrm{C}$. Integration of the peaks from standard solutions of atrazine were performed with a Shimadzu C-R3A 
integrator. The areas obtained from the integrator were checked by the triangulation method to insure consistency. Recoveries from the extraction precedure averaged $85 \pm$ 5 percent. Analysis of water blanks produced background levels of $0.71 \pm 0.65 \mathrm{ppb}$ atrazine. In the analysis of runoff samples, atrazine concentrations below $1.5 \mathrm{ppb}$ were considered trace amounts.

A procedural test was performed to determine if the storage procedure for runoff samples was effecient in preventing degradation of atrazine in the interim between sampling and extraction. Eight unfiltered runoff samples were spiked with a known amount of atrazine and stored at $4^{\circ} \mathrm{C}$ for 3 months. The samples were then filtered, extracted, and injected twice into the gas chromatograph. The first injection consisted of 5 microliters of sample, and the second injection was composed of a 5 microliters of sample plus an internal standard of atrazine. Upon comparison of the chromatograms, there was no indication that the atrazine had undergone any significant degradation. 


\section{CHAPTER 4}

\section{RESULTS OF RUNOFF AND SOIL LOSS}

\subsection{Rainfall}

Total precipitation for the two collection periods(June through November) in 1985 and 1986 was 88.2 and $68.2 \mathrm{~cm}$, respectively (Table 2 ). Based on the long-term rainfall record (22 years), rainfall was 34 and 14 percent higher, respectively, than the expected mean total of 58.7 for the 6 month collection period (NOAA, 1981).

Rainfall distribution was considerably different during each collection period. Rainfall was 4.3 and $16.6 \mathrm{~cm}$ above normal during the first 8 weeks of the growing season in 1985 and 1986, respectively. During this initial part of the growing season soil erosion can be the most dramatic because the soil surface has been disturbed by tillage and there is minimal protective crop canopy. During the middle of the growing season, when a full crop canopy has been established, rainfall was $17.5 \mathrm{~cm}$ above normal in 1985 and $8.8 \mathrm{~cm}$ below normal in 1986. After harvest and during the establishment of the winter cover crop, rainfall was similar in both years with totals of $7.6 \mathrm{~cm}$ and $5.7 \mathrm{~cm}$ above normal in 1985 and 1986, respectively. 
Table 2. Comparison of Monthly Precipitation to Monthly Means of 22 Year Rainfall Record

Kingston Weather Station, Kingston, RI

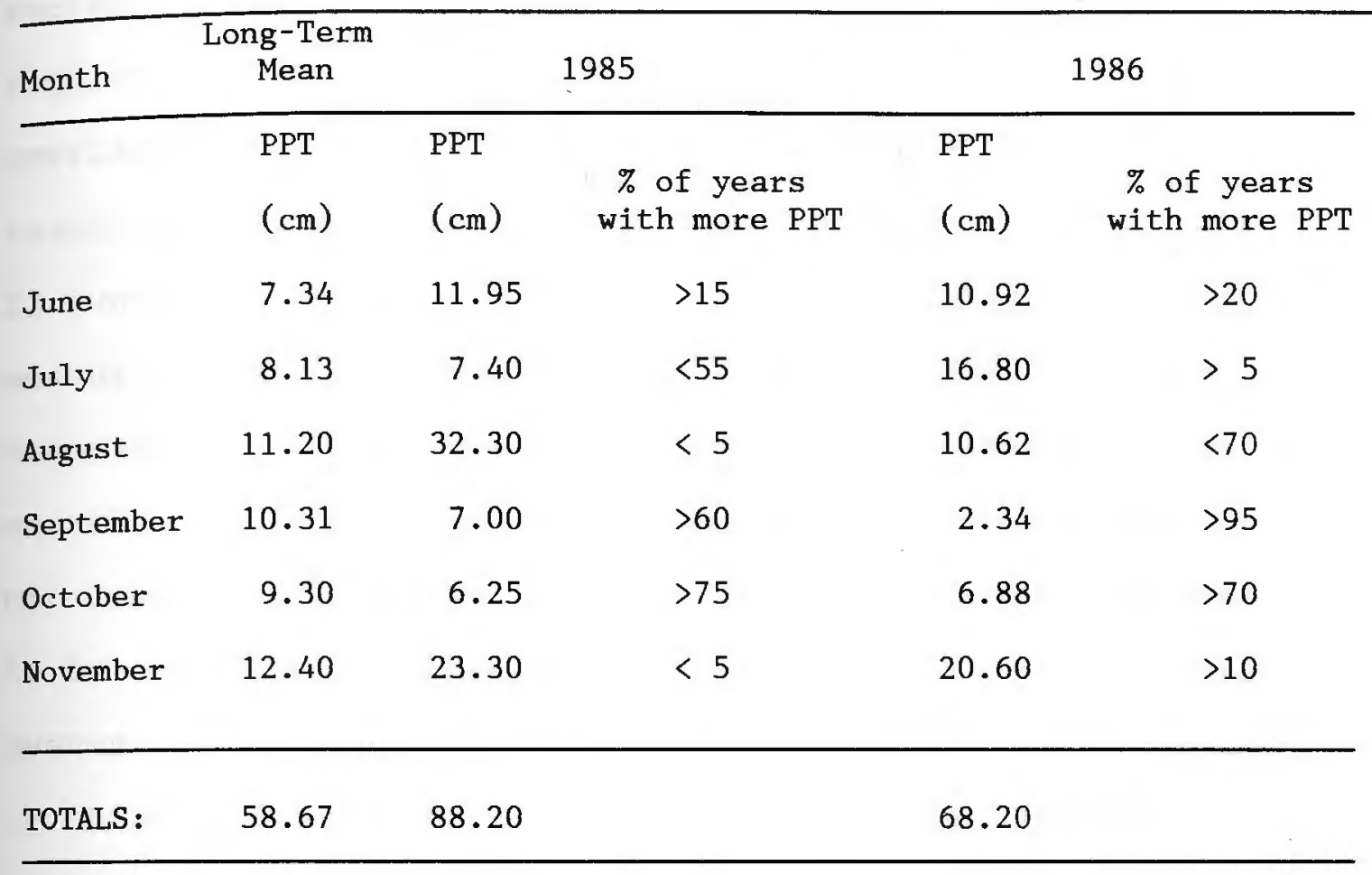




\subsection{Runoff}

Precipitation totals, storm characteristics, and the average runoff totals for each treatment are summarized for each event in Table 3. During the two collection periods, overland flow occurred on at least one plot in 22 out of 51 rainfall events. Due to outlet failure, only 18 out of the 22 runoff events had valid runoff and soil loss measurements. During the other 4 events, runoff was observed on all the plots but could not be measured on one-third of the plots. The data for these four events was not used in the analysis of results, but the results appear to be consistent with results obtained in the other 18 events.

A non-parametric statistical analysis was conducted by using the Friedman two-way analysis of variance test in which runoff depth for each treatment was ranked within each event (Daniel, 1978). This method is able to accommodate the large variability that occurs between events due to differences in rainfall volumes, rainfall intensity, canopy cover and antecedent soil moisture conditions. The test indicates that chisel without the rye cover had significantly greater $(p=.05)$ runoff than all other treatments except conventional without rye cover (Table 3 ). Conventional tillage without rye cover also had significantly more runoff than chisel with rye cover and no-till with rye cover. Chisel with rye cover had 
Table 3. Hydrological Summary

\begin{tabular}{|c|c|c|c|c|c|c|c|c|c|c|c|}
\hline \multirow[b]{2}{*}{$\begin{array}{l}\text { Runoff } \\
\text { Event }\end{array}$} & \multicolumn{4}{|c|}{ Storm Characteristics } & \multirow[b]{2}{*}{$\begin{array}{l}\text { Crop } \\
\text { Stage }\end{array}$} & & & \multicolumn{2}{|c|}{ Runoff (mm) } & \multicolumn{2}{|c|}{ NOTILL } \\
\hline & $\begin{array}{l}\mathrm{PPT} T \\
\mathrm{~mm}\end{array}$ & $\begin{array}{l}\text { DUR } \\
\text { min }\end{array}$ & $\begin{array}{c}\mathrm{I}_{30} \\
\mathrm{~mm}\end{array}$ & $\begin{array}{l}\text { AMC5 } \\
\mathrm{mm}\end{array}$ & & $\begin{array}{c}\mathrm{CO} \\
\mathrm{RC} F\end{array}$ & NC & $\mathrm{RC}^{\mathrm{C}}$ & ${ }^{E L}$ NC & $\mathrm{RC}^{\mathrm{NO}}$ & NC \\
\hline $6 / 24 / 85$ & $9.5^{\S}$ & 15 & 9.5 & 0.0 & SB & 0.0 & 0.5 & 0.0 & 1.0 & 0.0 & 1.5 \\
\hline $6 / 29 / 85$ & 17.0 & 660 & 4.0 & 9.5 & SB & 0.0 & 0.5 & 0.0 & 0.5 & 0.0 & 1.0 \\
\hline $7 / 22 / 85$ & $14.5^{\S}$ & 90 & 20.0 & 6.0 & $\mathrm{P} 1$ & 3.0 & 1.0 & 0.0 & 2.5 & 0.0 & 2.0 \\
\hline $8 / 08 / 85$ & $31.0^{\S}$ & 400 & 13.0 & 0.0 & $\mathrm{P} 2$ & 5.5 & 5.5 & 1.5 & 10.0 & 2.5 & 5.0 \\
\hline $8 / 26 / 85$ & $100.5^{\S}$ & 1440 & 33.0 & 0.0 & P3 & 34.5 & 34.0 & 25.5 & 43.0 & 36.0 & 31.0 \\
\hline $9 / 06 / 85$ & $27.5^{\S}$ & 250 & 28.0 & 0.0 & P3 & 5.5 & 4.0 & 5.0 & 10.5 & 2.5 & 5.5 \\
\hline $9 / 09 / 85$ & 23.0 & 330 & 13.0 & 26.0 & P3 & 2.0 & 3.0 & 2.5 & 6.5 & 1.5 & 4.0 \\
\hline $11 / 05 / 85$ & 81.3 & 1260 & 12.0 & 0.0 & $\mathrm{P} 4$ & 25.5 & 24.5 & 25.0 & 30.0 & 24.0 & 20.5 \\
\hline $11 / 13 / 85$ & 18.0 & 515 & 5.0 & 0.0 & P4 & 0.5 & 1.5 & 0.0 & 4.0 & 1.0 & 3.0 \\
\hline $7 / 13 / 86$ & $47.0^{\S}$ & 485 & 20.3 & 4.3 & $\mathrm{P} 1$ & 15.0 & 13.5 & 3.0 & 16.0 & 6.5 & 14.0 \\
\hline $7 / 26 / 86$ & 29.0 & 720 & 7.6 & 0.0 & $\mathrm{P} 2$ & 0.0 & 2.0 & 0.0 & 2.5 & 0.5 & 1.0 \\
\hline $7 / 29 / 86$ & 26.0 & 405 & 6.3 & 29.0 & P3 & 2.5 & 5.5 & 0.0 & 5.0 & 0.0 & 2.0 \\
\hline $8 / 2 / 86$ & $17.8^{\S}$ & 30 & 17.8 & 26.0 & P3 & 0.5 & 2.0 & 0.0 & 2.5 & 0.5 & 0.5 \\
\hline
\end{tabular}


TABLE 3. (cont.)

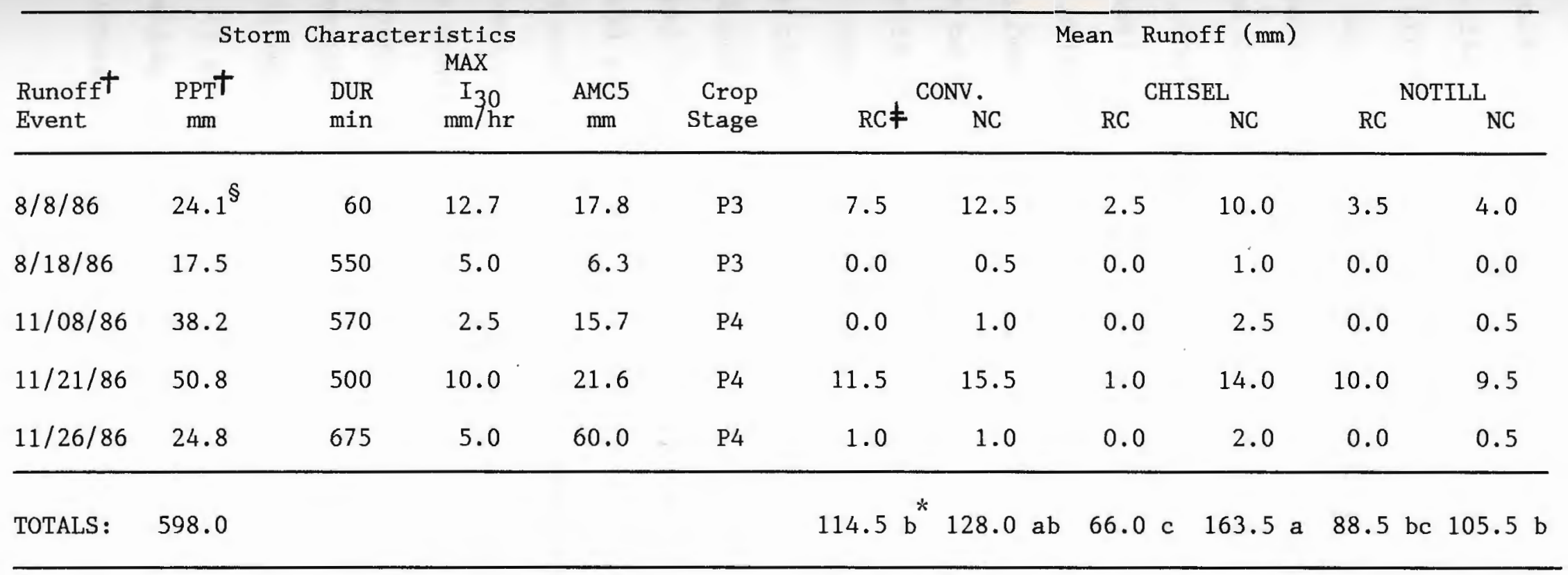

$+\mathrm{PPT}=$ precipitation tota1; $\mathrm{DUR}=$ storm duration; $\mathrm{MAX} \mathrm{I}_{30}=$ maximum 30 minute intensity; AMC5 = antecedent rainfall occurring within 5 days of event.

F $\mathrm{RC}=$ Rye Cover Crop; $\mathrm{NC}=$ No Cover Crop.

$\S$ Excessive rate storm is defined at $\mathrm{PPT} \geq 5+0.25 t$; where $t$ is storm duration in minutes.

* Mean runoff totals that are followed by the same letter are not significant1y different (0.05) based on the Friedman nonparametric two-way analysis of variance test. 
significantly less runoff than all other treatments except no-till with rye cover.

In the chisel plots without rye cover, surface sealing in the chisel furrows was observed after the first few rain events. These sealed furrows may have produced channelized flow down slope which might account for the large variation in runoff totals between chisel plots with the rye cover and chisel plots without rye cover. The surface sealing was not as evident on the chisel plots with rye cover. Lindstrom and onstad (1984) reported that higher infiltration rates can be maintained on fields with surface residue than on fields with bare soil.

Percent cover after tillage was 77 and 80 percent in the chisel and no-till systems with rye cover, respectively, and only 9 percent in the conventional system (Table 4). Based on SCSA defintion of conservation tillage systems ( >30 percent surface residue after planting), only chisel and notill with rye cover treatments can be classified as conservation tillage systems. (SCSA, 1982). Residue from the winter cover crop reduced total runoff by 60, 16, and 11 percent in the chisel, no-till, and conventional tillage treatments, respectively. Averaged over all three tillage treatments residue from the winter cover crop reduced runoff by 29 percent. Wendt and Burwell (1985) reported that crop residue from a winter cover crop reduced annual runoff volumes in no-till silage corn by approximately 50 percent. 
Table 4. Surface Residue After Tillage

\begin{tabular}{|c|c|c|c|c|c|c|}
\hline & \multicolumn{2}{|c|}{ Conventiona1 } & \multicolumn{2}{|c|}{ Chisel } & \multicolumn{2}{|c|}{ No-Ti11 } \\
\hline & $\mathrm{RC}$ & NC & $\mathrm{RC}$ & $\mathrm{NC}$ & $\mathrm{RC}$ & NC \\
\hline $\begin{array}{l}\text { Percent } \\
\text { cover }\end{array}$ & 9 & 6 & 72 & 14 & 85 & 16 \\
\hline $\mathrm{Kg} / \mathrm{ha}$ & 380 & 280 & 1420 & 430 & 1600 & 480 \\
\hline
\end{tabular}


A Erequency analysis was employed to analyze the frequency at which a specified runoff depth was exceeded within each treatment (Figure 2). In this analysis, runoff measurements from all twelve plots during the 18 runoff events were used instead of the mean value for each pair of replicates.

Cumulative frequency distributions of runoff depth for tillage treatments with rye cover show that the frequency of small runoff events ( $<12.5 \mathrm{~mm}$ ) was considerably higher in the conventional plots than no-till and chisel plots (Figure 2). No-till and chisel plots had no discernable differences in the freqency of large runoff events. Chisel plots had a lower frequency of the large runoff events than no-till and conventional plots. In 50 percent of the events, all treatments had at least $2 \mathrm{~mm}$ of runoff and in 20 percent of the events chisel and no-till had at least $3 \mathrm{~mm}$ of runoff while conventional plots had at least $6 \mathrm{~mm}$ of runoff.

The cumulative frequency distributions of runoff depth for tillage treatments without the rye cover show that no-till plots generated fewer small runoff events than the conventional and chisel plots. Chisel plots had a slightly higher frequency of the smaller runoff events than conventional tillage, but the frequency of the large runoff events were similar in all three tillage treatments. In contrast to the tillage treatments with rye cover, in 50 percent of the events chisel plots generated at 
Figure 2. Cumulative distribution functions showing the frequency of events that the given runoff depth was exceeded. 

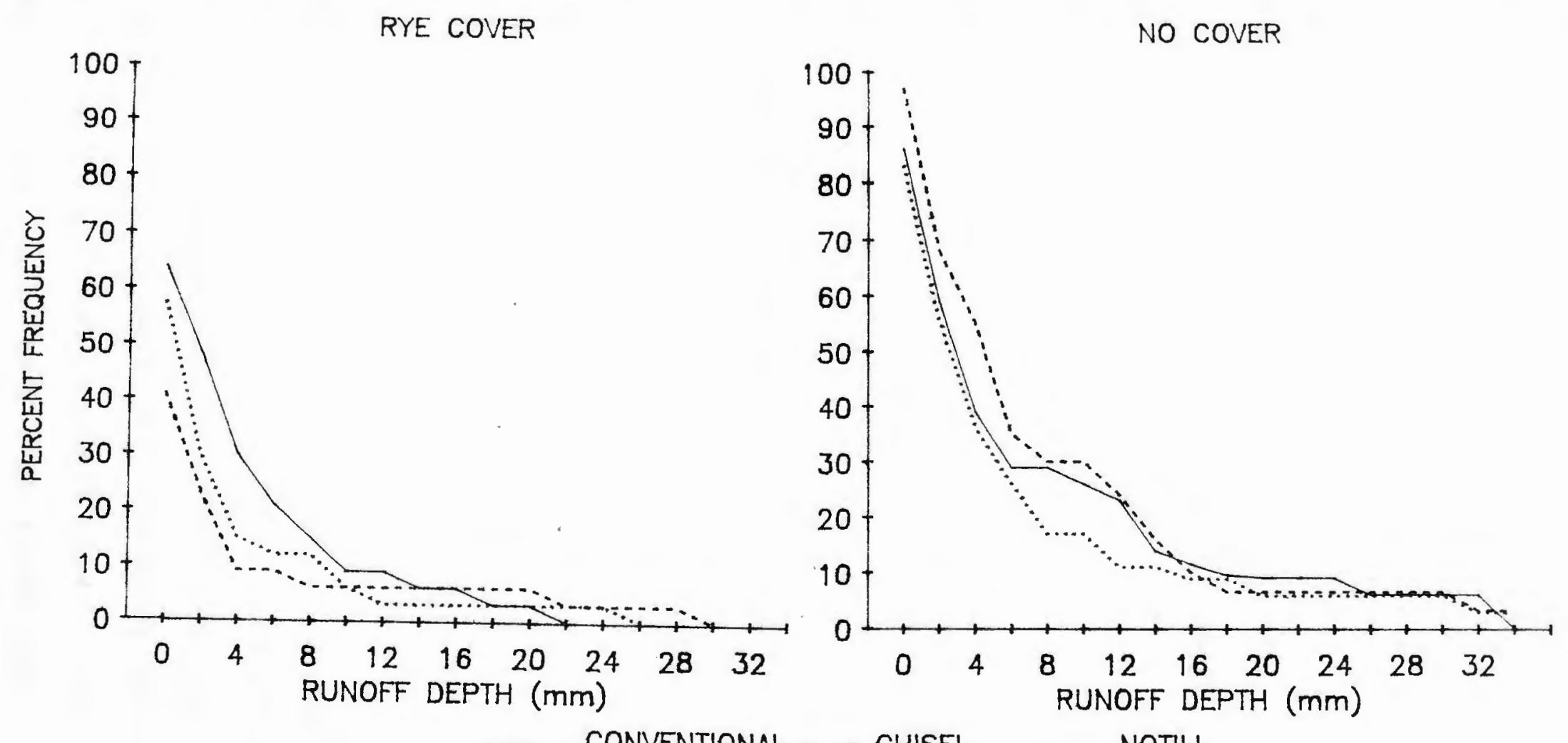

CONVENTIONAL - - CHISEL _..... NOTILL 
least $4 \mathrm{~mm}$ of runoff and conventional and no-till plots had at least $2.5 \mathrm{~mm}$ of runoff. On 20 percent of the events, conventional and chisel plots had at least $12 \mathrm{~mm}$ of runoff and no-till had at least $7 \mathrm{~mm}$ of runoff.

The higher frequency of small runoff events observed in the conventional plots with rye cover and in chisel plots without rye cover could have major ramifications on soluble pesticide losses, especially if the small events occur immediately after application.

\section{$4.3 \quad$ Soil loss}

Average soil loss totals for all treatments are summarized by event in Table 5. The Friedman nonparametric statistical test indicates that chisel without rye cover has significantly more soil loss $(\mathrm{p}=.05)$ than all treatments that had rye cover. Chisel with rye cover had significantly less soil loss than all treatments without rye cover.

The fact that the treatments ranked in almost the same order for both runoff and soil loss suggests that the two processes are closely related. Quansah (1983) found that higher runoff velocities can increase soil particle detachment, and larger runoff volumes are capable of transporting more sediment. Since conventional tillage with rye cover had more runoff but less soil loss than no-till without rye cover, it appears that rye cover has more of an effect on soil loss than on overland flow. In a 6 year study, Wendt and Burwell (1985) also found that without a 
Table 5. Soil Loss Summary

\begin{tabular}{|c|c|c|c|c|c|c|}
\hline \multirow{2}{*}{$\begin{array}{l}\text { Runoff } \\
\text { Event }\end{array}$} & \multicolumn{2}{|c|}{ Conventional } & \multicolumn{2}{|c|}{ Chise1 } & \multicolumn{2}{|c|}{ No-Ti11 } \\
\hline & $\mathrm{RC}$ & NC & $\mathrm{RC}$ & $\mathrm{NC}$ & $\mathrm{RC}$ & $\mathrm{NC}$ \\
\hline & $-\cdots-$ & $-\cdots-\cdots$ & $\cdots-$ & ha --. & - & --- \\
\hline $6 / 24 / 85^{\dagger}$ & 0.0 & 205.0 & 0.0 & 166.5 & 0.0 & 121.5 \\
\hline $6 / 29 / 85$ & 0.0 & 30.0 & 0.0 & 129.0 & 0.0 & 21.5 \\
\hline $7 / 22 / 85^{\dagger}$ & 69.5 & 58.0 & 0.0 & 312.5 & 0.0 & 48.0 \\
\hline $8 / 8 / 85^{\dagger}$ & 53.0 & 67.0 & 10.0 & 255.0 & 56.0 & 72.0 \\
\hline $8 / 26 / 85^{\dagger}$ & 132.5 & 83.5 & 93.5 & 790.5 & 241.5 & 265.5 \\
\hline $9 / 6 / 85^{\dagger}$ & 38.0 & 27.5 & 18.0 & 78.0 & 38.5 & 38.0 \\
\hline $9 / 9 / 85$ & 3.5 & 6.0 & 7.5 & 24.5 & 4.0 & 11.0 \\
\hline $11 / 5 / 85$ & 54.0 & 32.5 & 87.0 & 114.0 & 73.5 & 67.0 \\
\hline $11 / 13 / 85$ & 0.0 & 0.5 & 0.0 & 9.0 & 1.5 & 3.0 \\
\hline $7 / 13 / 86$ & 309.5 & 335.0 & 56.0 & 137.0 & 102.0 & 265.0 \\
\hline $7 / 26 / 86$ & 1.0 & 4.5 & 0.0 & 35.5 & 5.0 & 1.5 \\
\hline $7 / 29 / 86$ & 7.5 & 11.0 & 0.0 & 17.5 & 0.5 & 9.0 \\
\hline $8 / 2 / 86^{\dagger}$ & 4.0 & 8.5 & 10.0 & 42.0 & 28.0 & 16.5 \\
\hline $8 / 8 / 86^{\dagger}$ & 25.5 & 97.0 & 24.0 & 89.0 & 22.5 & 48.0 \\
\hline $8 / 18 / 86$ & 0.0 & 1.0 & 0.0 & 0.5 & 0.0 & 0.0 \\
\hline $11 / 8 / 86$ & 0.0 & 2.0 & 0.0 & 8.0 & 0.0 & 1.0 \\
\hline $11 / 21 / 86$ & 182.5 & 252.5 & 26.3 & 246.0 & 60.0 & 207.5 \\
\hline $11 / 26 / 86$ & 14.5 & 16.5 & 0.0 & 49.0 & 2.0 & 7.0 \\
\hline
\end{tabular}

TOTAL: $\quad 895.0 \mathrm{~b}^{*} 1238.0$ ab 300.0 a 2503.5 a 635.0 bc $1203.0 \mathrm{ab}$

$\dagger_{\text {Excessive rate storms }}$

Mean soil loss totals that are followed by the same letter are not significantly different $(0.05)$ based on the Friedman non-parametric two-way analysis of variance test. 
winter cover crop, no-till plots in corn-for-silage consistently had higher annual soil loss totals than no-till and conventional plots with the winter cover.

Chisel plots with rye cover averaged 88 percent less soil loss than the chisel plots without the rye cover. Soil loss in the conventional and notill plots with rye cover was 28 and 47 percent less, respectively, than that from the same tillage treatments without the rye cover. Averaged over all the treatments, rye cover reduced soil loss by 54 percent. The additional percent reduction in soil loss within tillage treatments, as compared to the percent reduction in runoff, might be attributable to a decrease in soil particle detachment as a result of lower runoff velocities and increased dispersion rainfall energy. The additional surface roughness caused by the rye cover can also provide surface detention time for overland flow, which would allow sediment particles to settle out.

Cumulative frequency distributions of tillage treatments with rye cover show that the frequency of the small soil loss events were similar in both the conventional plots and chisel plots, but the frequency of larger soil loss events was considerably higher in the conventional plots (Figure 3). No-till plots had a considerably lower frequency of occurrence than the chisel and conventional plots for all specified soil loss values. In 50 percent of the events chisel and no-till plots had no soil loss whereas conventionally tilled plots had at least $10 \mathrm{~kg} / \mathrm{ha}$ of soil 
Figure 3. Cumulative distribution functions showing the frequency of events that the given soil loss value was exceeded. 
RYE COVER

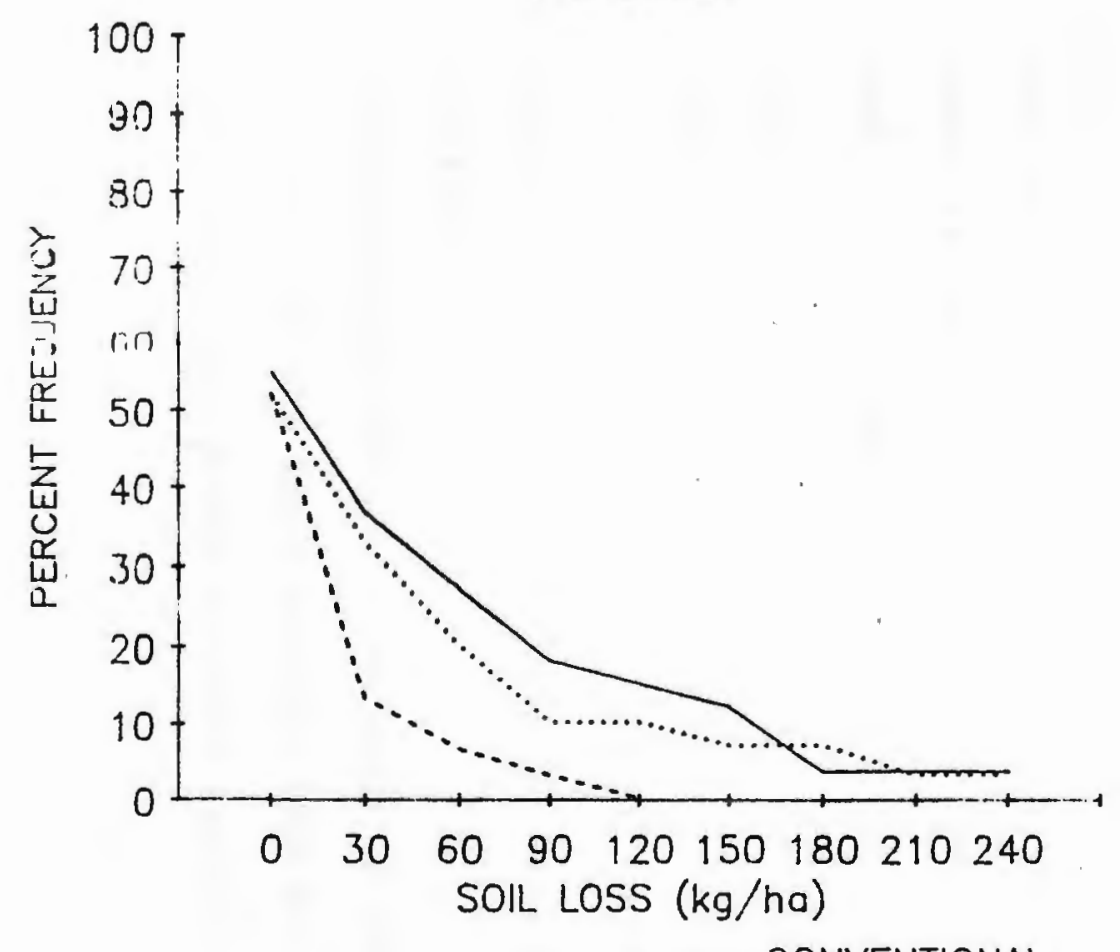

NO COVER

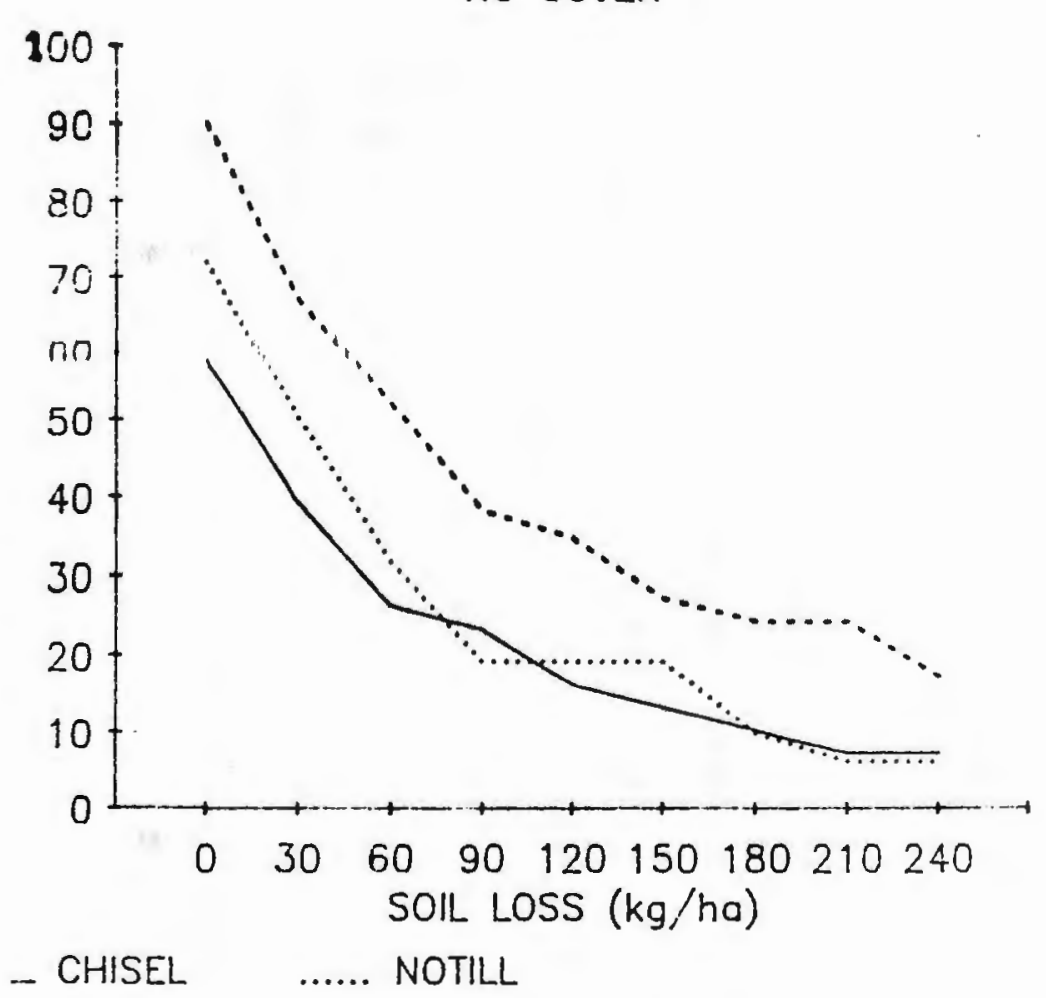


loss. On 20 percent of the events, conventional, no-till, and chisel plots had at least 80,60 , and $20 \mathrm{~kg} / \mathrm{ha}$ of soil 10ss, respectively.

Cumulative frequency distributions of tillage treatments without rye cover show that the frequency of exceedance for all specified soil loss values was considerably higher in the chisel plots than the notill and conventional plots. Notill and chisel plots had no discernable differences in the frequency of exceedance for all the specified soil loss values. On 50 percent of the events, conventional, no-till, and chisel plots had at least 10,30 , and $60 \mathrm{~kg} / \mathrm{ha}$ of soil loss, respectively. On 20 percent of the events, conventional, no-till, and chisel plots had at least 100, 90 , and $230 \mathrm{~kg} / \mathrm{ha}$ of soil loss, respectively.

High sediment concentrations were associated with tillage disturbance, crop canopy, and rainfall intensity (Table 6). The highest concentrations were observed in the runoff from chisel and conventional tillage plots in storms occurring within several weeks after planting in the 1985 season. Sediment concentrations steadily declined as the season progressed in both conventional and chisel tillage systems, whereas concentrations in the runoff from no-till plots varied throughout the season.

Sediment concentrations were not as high in the first runoff event occurring in the 1986 season. The soil surface is likely to have stabilized prior to this runoff event 
Table 6. Mean Sediment Concentration

\begin{tabular}{|c|c|c|c|c|c|c|}
\hline \multirow{2}{*}{$\begin{array}{l}\text { Runoff } \\
\text { Event }\end{array}$} & \multicolumn{2}{|c|}{ Conventional } & \multicolumn{2}{|c|}{ Chisel } & \multicolumn{2}{|c|}{ No-Till } \\
\hline & $\mathrm{RC}$ & NC & $\mathrm{RC}$ & NC & $\mathrm{RC}$ & NC \\
\hline \multicolumn{7}{|c|}{ - } \\
\hline $6 / 24 / 85^{\dagger}$ & 0 & 22,241 & 0 & 20,752 & 0 & 7919 \\
\hline $6 / 29 / 85$ & 0 & 4680 & 0 & 22,856 & 0 & 1954 \\
\hline $7 / 22 / 85^{\dagger}$ & 2383 & 4884 & 0 & 10,547 & 0 & 2995 \\
\hline $8 / 8 / 85$ t & 951 & 852 & 671 & 2570 & 2040 & 1333 \\
\hline $8 / 26 / 85^{\dagger}$ & 378 & 198 & 367 & 1213 & 483 & 800 \\
\hline $9 / 6 / 85$ & 717 & 508 & 336 & 746 & 800 & 789 \\
\hline $9 / 9 / 85$ & 201 & 205 & 274 & 390 & 277 & 273 \\
\hline $11 / 5 / 85$ & 360 & 129 & 334 & 264 & 269 & 284 \\
\hline $11 / 13 / 85$ & 0 & 140 & 0 & 220 & 200 & 200 \\
\hline $7 / 13 / 86^{t}$ & 2054 & 2525 & 1955 & 855 & 1550 & 1913 \\
\hline $7 / 26 / 86$ & 444 & 210 & 0 & 1427 & 1200 & 162 \\
\hline $7 / 29 / 86$ & 318 & 850 & 0 & 358 & 0 & 382 \\
\hline $8 / 2 / 86$ T & 1334 & 418 & 0 & 1790 & 5787 & 2570 \\
\hline $8 / 8 / 86$ † & 334 & 773 & 853 & 903 & 617 & 1154 \\
\hline $8 / 18 / 86$ & 0 & 156 & 0 & 115 & 0 & 0 \\
\hline $11 / 8 / 86$ & 0 & 241 & 0 & 356 & 0 & 405 \\
\hline $11 / 21 / 86$ & 1621 & 1634 & 2136 & 1745 & 593 & 2177 \\
\hline $11 / 26 / 86$ & 1639 & 2095 & 0 & 2840 & 0 & 1970 \\
\hline
\end{tabular}

FLOW-

WEIGHTED

MEAN:

781

967

454

1536

717

1140

$T_{\text {Excessive rate storms }}$ 
because of several non-runoff producing storms that occurred in the early season.

Several excessive rate storms, including the largest storm collected (Aug. 26, 1985), occurred during the cropstage P3 which is when the crop canopy is fully developed (Wischmeier and Smith, 1978). Sediment concentrations during these events were generally lower than in less intense rain events that occurred during other crop stages. This demonstrates the effectiveness of crop canopy in reducing erosive storm energy.

\subsection{Event-based Analysis}

The majority of the soil loss and overland flow that occurred during both seasons was associated with the eight excessive rate storms that occurred over the two seasons of study. An excessive rate storm is defined by the National weather service as a storm which produces a volume (mm) greater than or equal to $5+0.25 t$, where $t$ is the storm duration (minutes). Although these storms represented only 17 percent of the total precipitation during the study, they generated 57 to 67 percent of the total runoff and 70 to 77 percent of the total soil loss from all six treatments. Greer (1971) found during a 6 year study that excessive rate storms generated 77 percent of the soil loss.

Rye cover appears to be more effective in reducing runoff volume on the smaller events than on the larger events. In runoff events that had less than $25.4 \mathrm{~mm}$ of 
rainfall, conventional, no-till, and chisel plots with rye cover had 36, 61, and 84 percent less runoff, respectively, than the same tillage treatments without rye cover. In comparison to the total runoff generated in the 18 events, runoff from the conventional, no-till, and chisel plots with fye cover was 11, 16, and 60 percent less, respectively, than the same tillage treatments without rye cover. Surface residue provides a finite amount of depressional storage because of the additional surface roughness. This depressional storage contains a large portion of the rainfall volume on small events but has a minimal effect on large events where the depressional storage is readily satisfied.

Observed runoff volumes tended to be similar during the large storms in both plots with rye cover and without rye cover in all three tillage treatments. Considering that small rainfall events are more frequent than large rainfall events, the effect of rye cover on runoff in small events can have a tremendous effect on the seasonal losses of soluble pesticides and nutrients.

Rye cover also had a major influence on the occurrence of runoff. During 7 of the 18 events, plots with less than 20 percent surface residue cover generated runoff but the plots within the same tillage treatment that had substantial rye cover had no runoff (Table 3 ). This effect on the occurrence of runoff was even more apparent during the early season events that occurred in the seedbed cropstage of 
1985. The conservation tillage systems generated no runoff in the first three storms except for the conventional plots that had runoff in the third storm. Kramer (1984) also noted that for small runoff events occurring in the seedbed cropstage, runoff was less frequent in conservation tillage than in coventional tillage.

Reducing the occurrence of runoff in the early season events has important ramifications on the offsite losses of soluble agrichemicals and nutrients. Higher losses of chemicals and nutrients can be expected in the early season events when fertilizers and pesticides have been recently applied (Baker and Johnson, 1979). Hall (1974) found that 87 to 93 percent of the total seasonal loss of atrazine occurred in the first five runoff events following application.

Soil loss, generated in the early season events of 1985, was also considerably high even though runoff volumes were relatively small (Tables 2 and 4 ). In the chisel, no-till, and conventional treatments without rye cover 9, 17.5, and 40.5 percent of the the total seasonal soil loss occurred on the first event (June 24). On the same event, less than 2 percent of the total seasonal runoff occurred in all three treatments. When the soil loss from the two subsequent storms are included, percentages of the total seasonal soil loss increase to $23.5,32$, and 58 percent for the chisel, 
no-till, and conventional treatments without rye cover, respectively.

The large sediment movement observed on plots without cover in early storms is indicative of the vulnerability of the soil to particle detachment as a result of tillage disturbances. Sediment concentrations were excessive in the runoff from chisel and conventionaly-tilled plots in the the first three of the four events of 1985. High losses of adsorbed pesticides and nutrients can also be expected during the early part of the growing season. 
CHAPTER 5

AGRICHEMICAL LOSSES

5.1 Nitrogen loss in runoff

Total nitrogen losses ( $\mathrm{TKN}$ and $\mathrm{NO}_{3}-\mathrm{N}$ ) through overland flow during the 1986 growing season ranged from 0.33 to $3.42 \mathrm{~kg} / \mathrm{ha}$ or 0.1 to 1.3 percent of the applied nitrogen (Table 7). Chisel plots with rye cover reduced total nitrogen losses by 86 percent relative to conventional tillage plots with rye cover. No-till plots had an average reduction in nitrogen loss of 66 percent compared to the average loss in conventional plots.

Total Kjeldahl nitrogen accounted for 89.5 to 94 percent of the total nitrogen loss. The seasonal TKN losses were highest in the tillage treatments without rye cover (Table 7). Chisel, no-till, and conventional tillage without rye cover had 90.5, 58, and 27 percent more TKN losses, respectively, than the same tillage treatments with rye cover. These differences in TKN losses closely relate to the differences in soil loss within the same treatments in 1986. Total soil loss in chisel, no-till, and conventional tillage without rye cover was 82,63 , and 26 percent higher, respectively, than the same tillage treatment with rye cover.

Total Kjeldahl nitrogen, which is a measure of the cationic nitrogen species, adsorbs readily to sediment 
TABLE 7. Average Nitrogen Loading

\begin{tabular}{|c|c|c|c|}
\hline TREATMENT & TOTAL & TKN & $\mathrm{NO}_{3}-\mathrm{N}$ \\
\hline & ---- & /ha -- & ---- \\
\hline \multicolumn{4}{|l|}{ Conventiona1 } \\
\hline Rye Cover & 2.45 & 2.29 & 0.16 \\
\hline No Cover & 2.52 & 2.35 & 0.17 \\
\hline \multicolumn{4}{|l|}{ Chise1 } \\
\hline Rye Cover & 0.33 & 0.3 & 0.03 \\
\hline No Cover & 3.48 & 3.07 & 0.36 \\
\hline \multicolumn{4}{|l|}{ No-ti11 } \\
\hline Rye Cover & 0.97 & 0.88 & 0.09 \\
\hline No Cover & 1.93 & 1.81 & 0.12 \\
\hline
\end{tabular}


particles and remains in the "runoff-mixing" zone of the soil profile for extended periods following application. Nitrate- $\mathrm{N}$ is anoinic form of nitrogen and leaches out of the "runoff-mixing" zone rather quickly.

on an event basis, the greatest losses of TKN were associated with the events that had the largest amount of sediment movement. On all twelve plots, 66 to 96 percent of the seasonal TKN loss occurred on July 13 and November 21 . These two events also generated 60 to 94 percent of the total soil loss that occurred in 1986. Other studies have also documented that high percentages of the total nitrogen removed are associated with large sediment movement (Romkens et al., 1973; McDowell and McGregor, 1980).

Total nitrate loading through runoff was particularly low for all treatments and only accounted for 6 to 11 percent of the total nitrogen loss. As with TKN, higher nitrate losses were also apparent in tillage treatments without rye cover. Chisel and no-till treatments with rye cover had 80 and 40 percent less nitrate loss compared to conventional tillage with rye cover. Baker and Laflen (1982) reported an 82 percent reduction in nitrate loading on plots with $1500 \mathrm{~kg} / \mathrm{ha}$ residue compared to plots with no residue, even though flow-weighted means were similar. In a extensive review of the literature, Baker and Laflen (1982) stated that seasonal losses of nitrate-N in overland flow generally range between 1.0 and $2.7 \mathrm{~kg} / \mathrm{ha}$, however losses 
through leaching can be as high as $20.0 \mathrm{~kg} / \mathrm{ha}$ with $10.0 \mathrm{~cm}$ of percolation.

\subsection{Nitrogen Concentrations in Runoff}

Flow-weighted mean concentrations of nitrate-N ranged from 0.0 to $1.68 \mathrm{ppm}$, while flow-weighted mean concentrations of TKN ranged from 0.3 to 11.1 ppm (Tables 8 and 9). The Freidman nonparametric statistical test demonstrated no significant differences between treatments for flow-weighted mean concentrations of $\mathrm{NO}_{3}-\mathrm{N}$ or $\mathrm{TKN}$ in the 9 runoff events occurring in the 1986 season.

The observed flow weighted mean concentrations of nitrate during the 1986 season are extremely low (Table 8). Baker and Laflen (1982) reported flow weighted mean concentrations of $\mathrm{NO}_{3}-\mathrm{N}$ ranging from 3.9 to $4.7 \mathrm{ppm}$ in runoff from field plots fertilized with $143 \mathrm{~kg} / \mathrm{ha}$ of nitrogen. Romkens et al. (1973) reported average $\mathrm{NO}_{3}-\mathrm{N}$ concentrations ranging from 0.65 to $72.04 \mathrm{ppm}$ in runoff from field plots fertilized with $170 \mathrm{~kg} / \mathrm{ha}$ of nitrogen. Smolen (1986) observed a flow-weighted mean of $0.026 \mathrm{ppm}$ in a control watershed that had no agricultural activity.

The timing of the first runoff event following fertilization may have contributed to the low nitrate concentrations observed in the first runoff event. In order for high concentrations of nitrate to appear in this event, the organic nitrogen in the urea fertilizer would had to have undergone both ammonification and nitrification 
Table 8. Flow-weighted Mean Nitrate Concentration

\begin{tabular}{lllllll}
\hline Runoff & \multicolumn{2}{c}{ Conventional } & \multicolumn{2}{c}{ Chisel No-Till } \\
Event & RC & NC & RC & NC & RC & NC \\
\hline $7 / 13 / 86$ & 0.60 & 0.34 & 0.42 & 0.53 & 0.76 & 0.60 \\
$7 / 26 / 86$ & 0.52 & 0.27 & 0.0 & 1.68 & 0.48 & 0.52 \\
$7 / 29 / 86$ & 0.78 & 0.32 & 0.0 & 1.00 & 0.80 & 0.78 \\
$8 / 2 / 86$ & 0.70 & 0.68 & 0.08 & 0.85 & 0.62 & 0.85 \\
$8 / 8 / 86$ & 0.39 & 0.57 & 0.71 & 0.75 & 0.83 & 0.66 \\
$8 / 18 / 86$ & NR & 0.09 & NR & 0.35 & NR & NR \\
$11 / 8 / 86$ & NR & 0.55 & NR & 0.35 & NR & 0.34 \\
$11 / 21 / 86$ & 0.07 & 0.09 & 0.0 & 0.27 & 0.05 & 0.04 \\
$11 / 26 / 86$ & 0.57 & 0.38 & NR & 0.29 & NR & 0.57 \\
\hline Seasonal & 0.40 & 0.40 & 0.46 & 0.60 & 0.44 & 0.38 \\
Mean: & & & & & & \\
NR = No Runoff & & & & & &
\end{tabular}


Table 9. Flow-Weighted Mean TKN Concentration

\begin{tabular}{lllllll}
\hline Runoff & \multicolumn{2}{c}{ Conventiona1 } & \multicolumn{2}{c}{ Chisel } & \multicolumn{2}{c}{ No-Till } \\
Event & RC & NC & RC & NC & RC \\
\hline $7 / 13 / 86$ & 6.5 & 7.0 & 5.0 & 5.0 & 4.6 & 5.2 \\
$7 / 26 / 86$ & 5.0 & 3.3 & NR & 5.0 & 5.1 & 4.6 \\
$7 / 29 / 86$ & 2.7 & 2.8 & 2.5 & 3.6 & 2.7 & 7.1 \\
$8 / 2 / 86$ & 1.9 & 2.0 & 2.5 & 3.9 & 6.8 & 3.5 \\
$8 / 8 / 86$ & 4.7 & 2.2 & 3.9 & 3.6 & 2.6 & 4.8 \\
$8 / 18 / 86$ & $\mathrm{NR}$ & 1.5 & $\mathrm{NR}$ & 0.3 & $\mathrm{NR}$ & $\mathrm{NR}$ \\
$11 / 8 / 86$ & 0.6 & 2.9 & $\mathrm{NR}$ & 4.0 & $\mathrm{NR}$ & 3.4 \\
$11 / 21 / 86$ & 7.0 & 5.4 & 6.2 & 9.9 & 3.5 & 7.1 \\
$11 / 26 / 86$ & 10.7 & 7.3 & $\mathrm{NR}$ & 11.1 & $\mathrm{NR}$ & 8.7 \\
\hline TOTAL: & 6.1 & 4.5 & 4.7 & 5.8 & 3.9 & 5.8 \\
\hline
\end{tabular}

$\mathrm{NR}=$ No Runoff 
processes within 48 hours. Even under optimum conditions these transformations would be expected to take at least 5 to 7 days (Keaney, 1973).

Following the first runoff event, a considerable amount $(27.5 \mathrm{~mm})$ of non-runoff producing rainfall occurred before in the next runoff event. Kanwar et al. (1985) showed that nitrate movement is primarily downward into the soil profile and between 40 and 90 percent of the nitrate present after surface application may leach below $30 \mathrm{~cm}$ in the first 12.7 cm of rainfall.

\subsection{Atrazine Concentrations in Runoff}

Atrazine concentrations in the runoff water ranged from trace amounts (< $1.5 \mathrm{ppb})$ to $275.6 \mathrm{ppb}$ (Table 10). Ninety-five percent of all the runoff samples analyzed had atrazine concentrations below $30 \mathrm{ppb}$. Treatment effects on atrazine concentrations were not obvious. Flow weighted mean concentrations in runoff were not significantly different between treatments according to the Friedman nonparametric statistical test. Triplett et al. (1978) also found that concentrations of atrazine in runoff water was not influenced by tillage method.

Highest concentrations of atrazine in runoff were observed on the first event of the 1985 season, 12 days after atrazine application. Concentrations on this event exceeded the $180 \mathrm{ppb}$ level considered to be the "no adverse effect" concentration by the National Research Institute 
Table 10. Flow-weighted Mean Concentrations of Atrazine in Runoff

\begin{tabular}{|c|c|c|c|c|c|c|}
\hline \multirow{2}{*}{$\begin{array}{l}\text { Runoff } \\
\text { Event }\end{array}$} & \multicolumn{2}{|c|}{ Conventional } & \multicolumn{2}{|c|}{ CHISEL } & \multicolumn{2}{|c|}{ NOTILL } \\
\hline & $\mathrm{RC}$ & NC & $\mathrm{RC}$ & NC & $\mathrm{RC}$ & NC \\
\hline the & $\cdots$ & 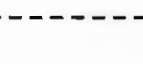 & $\cdots$ pr & $-\cdots-1$ & $\cdots$ & $--\cdots$ \\
\hline $6 / 24 / 85$ & $\mathrm{NR}$ & 275.6 & NR & 265.2 & NR & 229.6 \\
\hline $6 / 29 / 85$ & NR & 7.8 & $\mathrm{NR}$ & 19.0 & NR & 11.7 \\
\hline $7 / 22 / 85$ & 42.7 & 26.0 & NR & 26.5 & NR & 23.0 \\
\hline $8 / 08 / 85$ & 7.6 & 3.6 & 1.6 & 4.4 & 1.6 & 1.7 \\
\hline $8 / 26 / 85$ & $\operatorname{Tr}$ & $\operatorname{Tr}$ & $\operatorname{Tr}$ & $\operatorname{Tr}$ & $\operatorname{Tr}$ & $\operatorname{Tr}$ \\
\hline $9 / 06 / 85$ & 9.2 & 15.0 & 24.0 & 14.3 & 15.0 & 19.0 \\
\hline $9 / 09 / 85$ & 13.0 & 0.0 & 2.3 & 0.0 & $\operatorname{Tr}$ & 0.0 \\
\hline $7 / 13 / 86$ & 6.4 & 7.0 & 3.0 & 0.6 & 2.5 & 1.6 \\
\hline $7 / 26 / 86$ & NR & 2.5 & NR & 2.0 & 1.5 & 4.0 \\
\hline $7 / 29 / 86$ & 3.3 & 3.4 & NR & 0.0 & NR & 3.0 \\
\hline $8 / 2 / 86$ & 5.5 & $\operatorname{Tr}$ & NR & 0.0 & 0.0 & 4.0 \\
\hline $8 / 8 / 86$ & 0.0 & 5.4 & 0.0 & 2.0 & 0.0 & 0.0 \\
\hline $8 / 18 / 86$ & NR & 0.0 & NR & 0.0 & NR & NR \\
\hline
\end{tabular}

$\mathrm{NR}=$ No Runoff

$\operatorname{Tr}=$ Trace amounts means that atrazine was detected in the sample but concentrations were below the background levels. 
(1977). No treatments generated concentrations above the acceptable Health Guidance Limit of $375 \mathrm{ppb}$ for drinking water set by the National Agricultural Chemical Association (1985) •

Concentrations never exceeded $25 \mathrm{ppb}$ from any events that occurred more than 6 weeks after atrazine application. The general decline in measured runoff concentration as time after application increased, coincides with the results of the regression analysis performed by Triplett et al. (1978). A regression analysis of days after application vs. concentration of atrazine in runoff showed a significant negative correlation $(r=-0.90)$.

\subsection{Atrazine loss through runoff}

Seasonal atrazine losses for both growing seasons were very low with less than 0.01 percent of the applied atrazine being lost through runoff (Table 11). Substantial portions of the applied atrazine are likely to have leached out of the "runoff mixing zone" by non-runoff producing rainfall that occurred before the first runoff event in both seasons. Following atrazine application in 1985 and 1986, 30 and $150 \mathrm{~mm}$ of non-runoff producing rainfall occurred before the first runoff event, respectively. Other studies have demonstrated that significant amounts of atrazine can be lost through leaching (Whetje et al. 1984; Wu, 1980). Hall (1974) detected atrazine to a depth of $76 \mathrm{~cm}$ approximately 2 months after application. 
Table 11. Atrazine Loss in Runoff

1985 SEASON

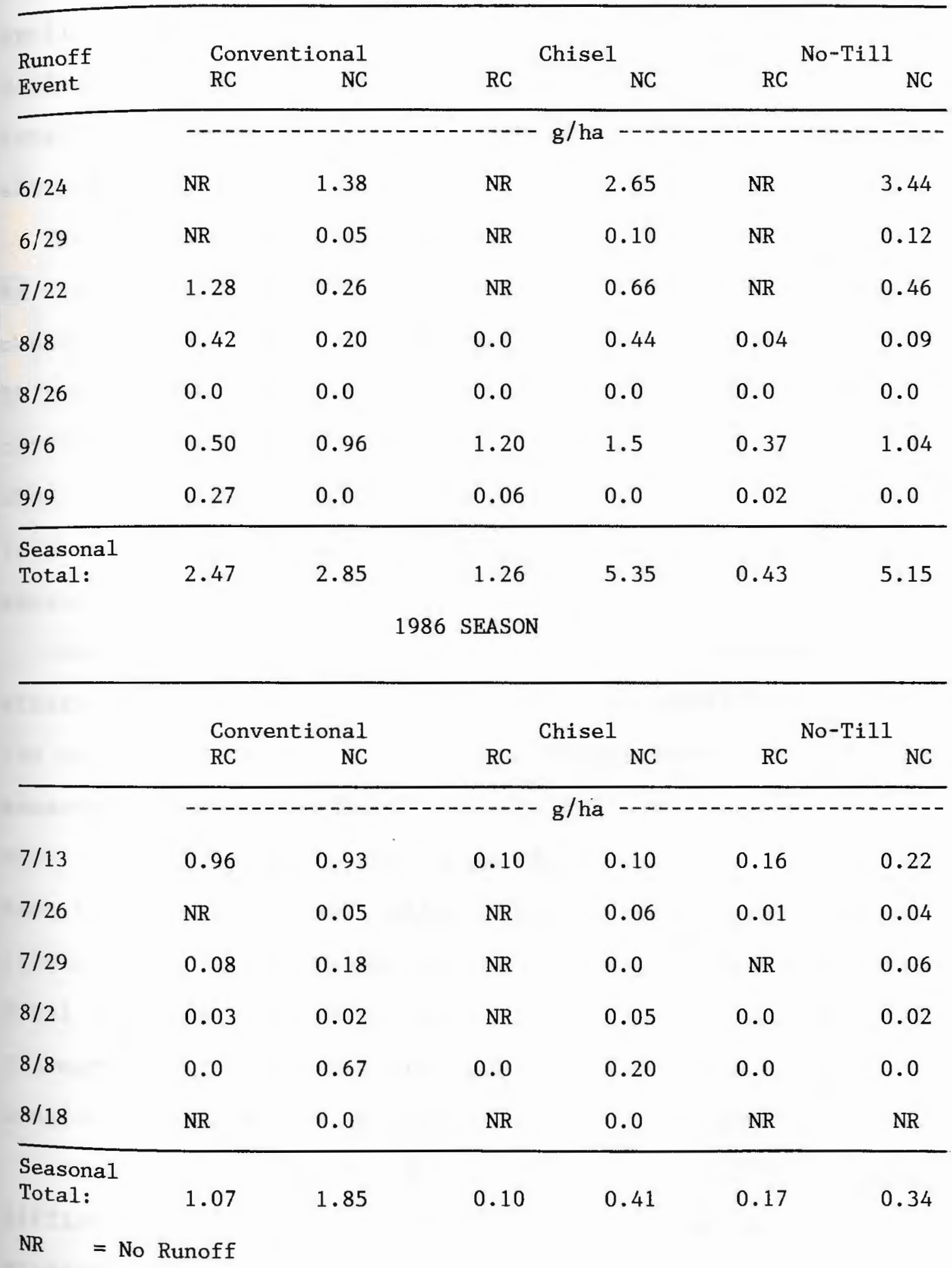


A considerable amount of the applied atrazine in the 1986 season may have degraded between the time of application (May 31) and the first runoff event (July 13). Hall et al. (1972) found that 60 percent of the applied atrazine was lost through degradation in the soil one month after application.

The timing of the first runoff-producing storm relative to application is very important in determining atrazine runoff losses. Baker and Johnson (1979) observed losses of 10 percent of the applied atrazine when an intense rainstorm occurred 24 hours after atrazine application. In contrast, when the first runoff-producing storm did not occur until at least 2 weeks after application, average total growing season losses were less than 2 percent.

Conservation tillage systems did influence seasonal atrazine losses considerably by reducing runoff volumes and the occurrence of runoff in early season events. Average seasonal losses of atrazine from chisel and notill plots with rye cover were 71 and 76 percent lower, respectively, than the same treatments without rye cover. Kenimer et al. (1986) reported that conservation tillage systems reduced total atrazine loss by 92 percent compared to that in conventional tillage because runoff volumes were considerably lower in conservation tillage systems.

Based on the results of this study, it would be difficult to make long-term predictions on the amount of atrazine that could be potentially lost through overland 
flow from corn-for-silage fields. During the two growing seasons of this study, a major runoff event did not occur until the month of July which resulted in low seasonal losses of atrazine. A computer model that provides continuous simulation of runoff, erosion, and chemical transport processes, by using long-term weather data, would greatly improve predictions of potential losses of atrazine from silage corn fields. 
CHAPTER 6

PERFORMANCE ASSESSMENT OF THE CREAMS HYDROLOGY COMPONENT

\subsection{Modeling Approach}

The CREAMS hydrology component incorporates two options for runoff prediction (Knisel, 1980). If only daily rainfall data is available, storm runoff is computed by using the Soil Conservation Service curve number method (U.S.SCS, 1972). Whenever hourly or breakpoint (time-intensity) rainfall data is available the Green-Ampt infiltration equation is used for runoff prediction. The mathematical formulas for each method are presented in next section.

Both runoff prediction options were utilized to estimate runoff from conventionally-tilled plots and no-till with rye cover plots during the 1985 and 1986.growing season. Initial values for the required parameters were selected from the recommended values specified by the CREAMS User's Manual to describe soil porperties and cover conditions in both treatments. Based on the differences between the amount of predicted runoff generated with the recommended values and the amount of runoff observed in the field, adjustments were made in selected input parameters (Table 12) to obtain the best fit of predicted values relative to observed values. Adjustments of parameter values were 
Iimited to the acceptable range of variation for the site conditions specified by Knisel (1980).

The predicted runoff values were compared to observed runoff values with several statistical tests. Although there is no standard procedure for evaluating differences between observed and predicted values, other researchers have found the following statistical tests useful for prediction/observation evaluations (Leggett and Williams, 1981; Thomann, 1982; Reckhow and Chapra, 1983).

1) Regression analysis of observed versus predicted runoff values:

A) A linear regression line representing a perfect fit of observed versus predicted values would appear as a 1:1 line with an intercept of 0 , and a slope of 1.0 . Therefore, to visually assess the goodness-of-fit between the observed and predicted runoff values, a linear regression line for each model simulation is plotted against a 1:1 line. A test of significance on the slope and intercept of the derived linear regression equation will also be performed. The test is based on the hypothesis:

$$
\begin{aligned}
& \mathrm{H}_{1}: \quad \mathrm{A}=0 \text { and } \mathrm{B}=1.0 ; \\
& \mathrm{H}_{2}: \quad \mathrm{A} \neq 0 \text { and } \mathrm{B} \neq 1.0 ;
\end{aligned}
$$

B) The coefficient of determination $\left(R^{2}\right)$ derived from the regression analysis is used to describe the degree of 
association between the observed and predicted values. $\mathrm{R}^{2}$ can range from -1.0 to 1.0 depending on whether the predicted values are negatively or positively associated with the observed values. The closer $R^{2}$ is to -1.0 or 1.0 the greater is the association between the predicted and the observed values.

3) Reliability Index ( $K$ ) developed by Leggett and Williams (1981) describes the magnitude to which predictions agree with observations. For $\mathrm{K}>1$, model predictions agree with observed values within a factor ranging from $1 / \mathrm{K}$ to $\mathrm{K}$ times the corresponding observed values. The closer $K$ is to one, the better the match between observations and predictions.

4) Root Mean Square Error (RMS Error): expressed as

$$
\text { RMS Error }=\left(\left(\Sigma\left(x_{i}-c_{i}\right)^{2} / N\right)^{1 / 2}\right.
$$

where $\mathrm{x}=$ observed values and $\mathrm{c}=$ predicted values. The advantage of the RMS Error is that it is a direct measure of model error so it is expressed in the units of the observed values. 
5) Paired Comparison t-test: expressed as

$$
t=\frac{\bar{d}}{s_{x}(N)^{1 / 2}}
$$

where $d$ is the mean difference between observed and the predicted values, and $s_{x}$ is the standard deviation. If the $t$ value generated by the equation is greater than the test statistic at the 0.05 level, then the null hypothesis $\mathrm{H}_{\mathrm{O}}: \mathrm{d}=0$ is rejected in favor of $\mathrm{H}_{1}: \mathrm{d}>0$. predicted values.

\subsection{Hydrology Component Description}

The curve number method (Option 1), as modified by Williams and Laseur (1976), relates direct runoff to daily rainfall as a function of a curve number. The curve number is a function of soil type, residue cover, management practice, and antecedent rainfall. Daily runoff, $\mathcal{Q}(\mathrm{mm})$ is related to daily rainfali, $P(\mathrm{~mm})$, a retention parameter, $\mathrm{S}(\mathrm{mm})$, and an initial abstraction parameter, Ia ( $\mathrm{mm})$, as

$$
Q=(P-I a)^{2} /(P-I a+S)
$$

Storage, $\mathrm{S}$, in equation (1) is determined daily from a soil-water accounting procedure as

$$
S=S_{\max }(U L-S M) / U L
$$


where UL is the upper limit of soil water storage in the root zone (mm) and SM is the soil-water content in the root zone $(\mathrm{mm})$. The maximum storage, $S_{\max }(\mathrm{mm})$, in equation (4) is estimated from the curve number for moisture condition I (CNI) by the relation

$$
S_{\max }=(25400 / \mathrm{CNI})-254
$$

CNI is determined from the curve number for moisture condition II (CN2), by the polynomial

$$
\begin{aligned}
\mathrm{CNI}= & -16.91+1.348(\mathrm{CN} 2)-0.01370(\mathrm{CN} 2)^{2}+ \\
& 0.0001179(\mathrm{CN} 2)^{3}
\end{aligned}
$$

The curve number, $\mathrm{CN} 2$, is entered into the CREAMS option 1 for a given soil cover complex and management system. CN2 is only used to estimate maximum soil-water storage and is not actually used to estimate daily runoff. This is the major difference between the procedure by williams and LaSeur (1976) and that of the U.S. Soil Conservation Service (1972).

The breakpoint intensity method (Option 2), is based on the Green and Ampt infiltration equation (Green and Ampt, 1911; Smith and Parlange, 1978). Infiltration is dependent upon antecedent moisture conditions in the surface layer (DS), which is analagous to the intial abstraction parameter in the SCS curve number method (Option 1). 
However, infiltration is also a function of rainfall intensity. When rainfall begins, the soil water content in the surface control layer approaches saturation and time to surface ponding is computed $(t p)$. After ponding, water is assumed to move downward as a sharply defined wetting front with a characteristic capillary tension (GA) as the principal driving force. The infiltrated depth (F) in a time interval ( $t$ ) is expressed as

$$
F=\left[4 A((G A * D)+F)+(F-A)^{2}\right]^{1 / 2}+A-F
$$

where $\mathrm{A}=\mathrm{RC}_{\mathrm{tp}} / 2, \mathrm{D}=\varphi \mathrm{s}-\varphi \mathrm{i}, \varphi \mathrm{s}=$ water content at saturation, $\varphi i=$ intital water content, and $\mathrm{RC}$ is the saturated infiltration rate $(\mathrm{mm} / \mathrm{hr})$. The infiltration-based model is highly sensitive to three parameters; GA, RC, and DS (Rudra et al. 1985).

Runoff is initiated when the precipitation rate for a given time period exceeds the infiltration rate for that time period. Infiltration rate and the resulting runoff are recomputed for each change in rainfall intensity. Surface detention and surface storage components are incorporated in the computation of the final edge-of-field runoff.

\subsection{Model Performance Assessment}

Using the recommended parameter values, runoff was generally underestimated in both management practices for both prediction methods. The recommended values for 
parameters describing soil properties were selected to represent the characteristics typical of a Hydrologic Group B soil (U.S.SCS, 1972). Hydrologic Group B soils are characterized as having a moderately low runoff potential and an above average saturated infiltration rate. According to the Rhode Island Soil Survey, the Enfield silt loam is classified as a Hydrologic Group B soil (U.S.SCS, 1981).

However, in order to achieve close agreement to observed runoff values using the curve number method, the curve number needed to be adjusted to reflect the characteristics of a Hyrologic Group C soil (Table 12). This adjustment goes beyond the recommended range of curve number values for this particular soil type. Hydrologic Group C soils are characterized as having a moderately high runoff potential and a lower saturated infiltration rate (U.S.SCS, 1972).

In comparison, best-fit parameter values used for the breakpoint intensity method were all within the acceptable range of values provided by the CREAMS User's Manual. The adjustments did, however, reflect a lower infiltration rate (Table 12). For the conventional tillage system, the saturated infiltration rate (RC) and the depth of the surface layer (DS) were reduced to the lowest acceptable value. For the no-till system, the best-fit parameter values were set at about midrange between the acceptable limits. 
Table 12. Recommended and Best-Fit Parameter Values used for the Hydrology Component of the CREAMS Model

Recommended

GA, Capillary Tension, cm

II. Curve Number Method

Curve Number
CONVENTIONAL

Best-fit

4.6

1.0

22.8

81

3.8

0.2

12.4

22.8

NO-TILL

Recommended

Best-fit

5.3

5.0

1.0

1.0

12.4 
The adjusted parameter values, used to represent lower infiltration rates, may be indicative of the surface sealing potential of the Enfield silt loam. As mentioned before, surface sealing was observed in the field in both seasons after several rainfall events occurred. Lemos and Lutz (1958) stated that the silt content is a significant soil parameter influencing structure and aggregate breakdown. The textural analysis of the $A$ horizon of the Enfield silt loam shows that 74 percent of the soil is composed of silt particles (P. Schauer, Resource Assoc. Natural Resources Science Dept., Soil Genesis, 1987, personal communication).

Linear regression lines of observed versus predicted runoff values were closest to a 1:1 line using the curve number method for the no-till and using the breakpoint intensity method in the conventional tillage system (Figures 4 and 5 ). Of the four statistical tests used to determine the validity of the CREAMS model, the Root Mean Square Error and the Reliability Index $(K)$ measures were the most useful (Tables 13 and 14). The plots of regression lines plotted against a 1:1 line were critical for delineating the obvious differences between predicted and observed values visually (Figures 4 and 5). The coefficient of determination $\left(R^{2}\right)$ and the paired comparison test had limited value for distinquishing differences in the model performance because all of these measures were significant at the 0.05 level. 
Table 13. Statistical Summary of the

Hydrology Component Assessment No-till with Rye Cover

$\begin{array}{cl}\text { Recommended } & \text { Best-Fit } \\ \text { Parameter values } & \text { Parameter }\end{array}$

I. Breakpoint Intensity Method

Obs. vs. Pred. Regression
a
0.79
1.10

$\mathrm{H}: \mathrm{A}=0$

Accept

Accept

b

0.27

0.42

$\mathrm{H}: \mathrm{B}=1$

$\mathrm{R}^{2}$

K

RMS Error (mm)

Paired comparison t-test

Number of storms with no runoff predicted

II. Curve Number Method

Obs. vs. Pred. Regression

$$
\text { a }
$$$$
-0.36
$$

Accept

0.46

Accept

$0.98^{*}$

4.50

3.38

2.42

10
$\mathrm{H}$ : $\mathrm{B}=1$

$$
\mathrm{R}^{2}
$$

$\mathrm{K}$

RMS Error (mm)

Paired comparison t-test

Number of storms with no runoff predicted
Accept

$$
0.67^{*}
$$

4.25

5.6

2.15

4
$-0.09$

Accept

1.04

Accept

$0.98^{*}$

3.30

1.12

2.49

5

$\star$

Significant at the 0.05 level.

ix's

Critical values for $t$-test; $t=1.729$ a the 0.05 level

$t=2.093$ a the 0.025 level 
Table 14. Statistical Summary of the

Hydrology Component Assessment-Conventional Tillage

\section{Recommended \\ Parameter values}

Best-Fit

Parameter

I. Breakpoint Intensity Method

Obs. vs. Pred. Regression
a
0.23
0.39

$\mathrm{H}: \mathrm{A}=0$

Accept

Accept

b

0.58

0.91

$\mathrm{H}: \mathrm{B}=1$

Accept

Accept

$\mathrm{R}^{2}$

$0.72^{*}$

$0.90^{*}$

K

5.11

3.90

RMS Error (mm)

4.90

1.73

Paired comparison t-test

$3.75^{* * *}$

4.00

Number of storms with no

4

2 runoff predicted

II. Curve Number Method

Obs. vs. Pred. Regression

$\begin{array}{ccc}\mathrm{a} & -0.86 & -0.80 \\ \mathrm{H}: \mathrm{A}=0 & \text { Accept } & \text { Accept } \\ \mathrm{b} & 0.77 & 1.06 \\ \mathrm{H}: \mathrm{B}=1 & \text { Accept } & \text { Accept } \\ \mathrm{R}^{2} & 0.54^{*} & 0.55^{*} \\ \mathrm{~K} & 3.80 & 2.50 \\ \mathrm{n} & 4.73 & 5.42 \\ \text { comparison t-test } & 3.64 & 3.60 \\ \text { of storms with no } & 8 & 5 \\ \text { (m) } & & \end{array}$

Significant at the 0.05 level.

***

Critical values for $t$-test; $t=1.729$ a the 0.05 level

$t=2.093$ a the 0.025 level 
Figure 4. Predicted versus observed runoff values for conventional treatment with corresponding linear regression lines plotted against a 1:1 line. 

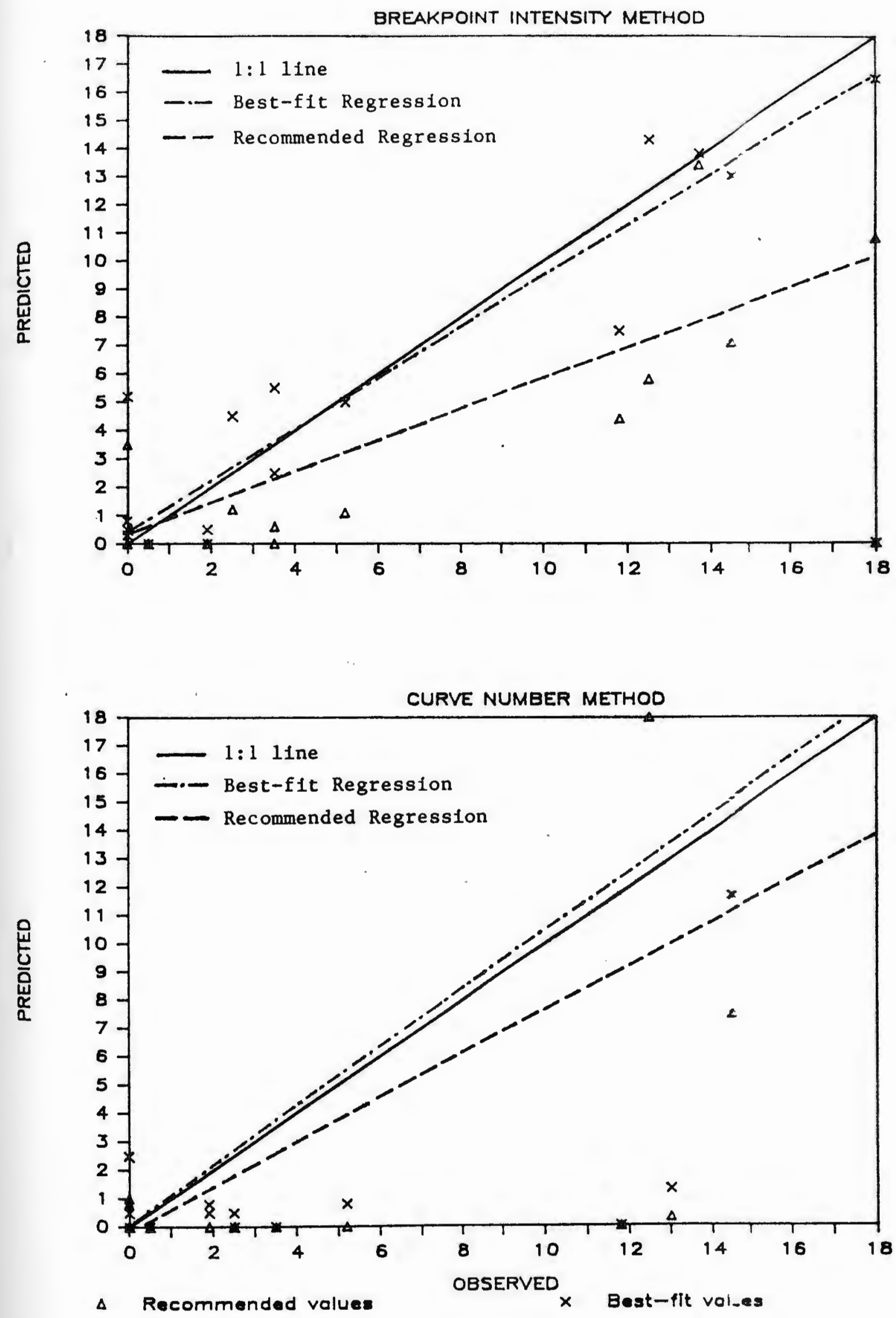
Figure 5. Predicted versus observed runoff values for the no-till with rye cover treatment with corresponding linear regression lines plotted against a $1: 1$ line. 

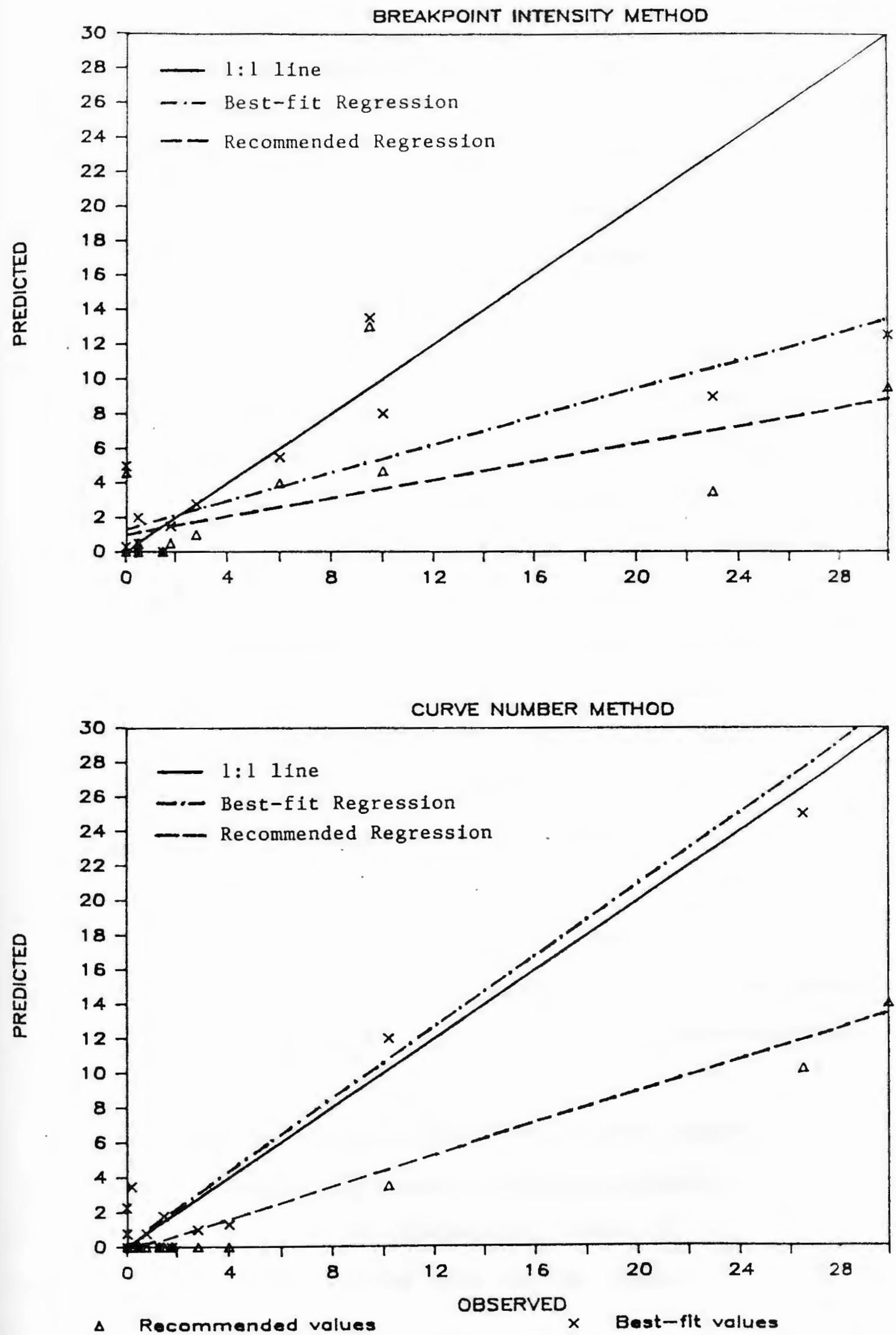
Both runoff prediction methods overpredicted runoff in the conventional tillage system during the early season events in the 1986 season (Table 15). Several rain events had predicted runoff when no runoff was observed. The overpredictions on these events most likely resulted because the infiltration rate in the field was probably much higher due to the disturbance to the soil surface from tillage.

Runoff was also overpredicted on several early season events in the the no-till treatment (Table 16). In this treatment as well, surface sealing is likely to occur after several rain events have occurred. Changes in the infiltration rate that occur in the field as a result of surface sealing cannot be simulated by the model. In order to achieve close agreement to observed runoff values on the the majority of the storms, which occurred later in the season, best-fit parameter values representing lower infiltration rates were required. However, the change in values was not as dramatic as in the conventional tillage (Table 12).

The breakpoint intensity method was much better at predicting runoff for small, intense storms than the curve number number method in the conventional tillage treatment (Figure 4).

Using the curve number method there were twice as many days where no runoff was predicted for an observed runoff event than when using the breakpoint intensity method. The curve number method depends more on the amount of 
Table 15. Comparison of Observed and Predicted Runoff for Conventional Tillage using Best-Fit Parameter Values

\begin{tabular}{|c|c|c|c|c|}
\hline Event & $\mathrm{PPT}$ & Observed & $\begin{array}{c}\text { Breakpoint Intensity } \\
\text { Method }\end{array}$ & $\begin{array}{c}\text { Curve-Number } \\
\text { Method }\end{array}$ \\
\hline & ----- & --------1 & 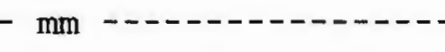 & ----------- \\
\hline $6 / 16 / 85$ & 20.0 & 0.0 & 0.5 & 0.0 \\
\hline $6 / 24 / 85^{\dagger}$ & 9.5 & 0.0 & 0.0 & 0.0 \\
\hline $6 / 29 / 86$ & 17.0 & 0.0 & 0.0 & 0.0 \\
\hline $7 / 22 / 85^{\top}$ & 14.5 & 0.5 & 0.0 & 0.0 \\
\hline $8 / 08 / 85^{t}$ & 31.0 & 2.5 & 4.5 & 1.0 \\
\hline $8 / 26 / 85^{\top}$ & 100.5 & 18.0 & 16.5 & 30.0 \\
\hline $9 / 06 / 85^{\dagger}$ & 27.5 & 3.5 & 2.5 & 0.0 \\
\hline $9 / 09 / 85$ & 23.0 & 3.5 & 5.5 & 0.0 \\
\hline $11 / 05 / 85$ & 81.5 & 12.5 & 14.3 & 25.4 \\
\hline $11 / 13 / 86$ & 21.0 & 0.0 & 0.0 & 0.0 \\
\hline $6 / 07 / 86$ & 32.0 & 0.0 & 5.2 & 0.5 \\
\hline $7 / 02 / 86$ & 9.0 & 0.0 & 0.8 & 2.5 \\
\hline $7 / 13 / 86^{\dagger}$ & 47.0 & 13.7 & 13.8 & 1.3 \\
\hline $7 / 27 / 86$ & 29.0 & 1.9 & 0.5 & 0.8 \\
\hline $7 / 29 / 86$ & 26.0 & 5.2 & 5.0 & 0.8 \\
\hline $8 / 02 / 86$ & 18.0 & 1.9 & 0.0 & 0.0 \\
\hline 8/08/86 & 24.0 & 11.8 & 7.5 & 0.5 \\
\hline $8 / 18 / 86$ & 17.5 & 0.0 & 0.3 & 0.0 \\
\hline $11 / 08 / 86$ & 38.0 & 0.0 & 0.0 & 2.5 \\
\hline $11 / 21 / 86$ & 51.0 & 14.5 & 13.0 & 11.7 \\
\hline $11 / 26 / 86$ & 25.0 & 0.5 & 0.0 & 0.0 \\
\hline TOTALS: & & 90.0 & 90.0 & 77.0 \\
\hline
\end{tabular}

$十_{\text {Excessive rate storm }}$ 
Table 16. Comparison of Observed and Predicted Runoff for No-til1 with Rye Cover using Best-Fit Parameter Values

\begin{tabular}{|c|c|c|c|c|}
\hline Event & PPT & Observed & $\begin{array}{c}\text { Breakpoint Intensity } \\
\text { Method }\end{array}$ & $\begin{array}{c}\text { Curve-Number } \\
\text { Method }\end{array}$ \\
\hline $6 / 16 / 85^{\top}$ & 20.0 & 0.0 & 0.3 & 0.0 \\
\hline $6 / 24 / 85$ & 9.5 & 0.0 & 0.0 & 0.0 \\
\hline $6 / 29 / 86$ & 17.0 & 0.0 & 0.0 & 0.0 \\
\hline $7 / 22 / 85 T$ & 14.5 & 0.0 & 0.0 & 0.0 \\
\hline $8 / 08 / 85^{\dagger}$ & 31.0 & 1.8 & 2.8 & 1.0 \\
\hline $8 / 26 / 85^{t}$ & 100.5 & 30.0 & 12.5 & 30.5 \\
\hline $9 / 06 / 85^{t}$ & 27.5 & 1.8 & 1.5 & 0.0 \\
\hline $9 / 09 / 85$ & 23.0 & 1.0 & 0.0 & 0.0 \\
\hline $11 / 05 / 85$ & 81.5 & 23.0 & 9.0 & 25.0 \\
\hline $11 / 13 / 86$ & 21.0 & 0.5 & 0.0 & 0.0 \\
\hline $6 / 07 / 86$ & 32.0 & 0.0 & 5.0 & 0.8 \\
\hline $7 / 02 / 86$ & 9.0 & 0.0 & 0.0 & 2.3 \\
\hline $7 / 13 / 86^{\dagger}$ & 47.0 & 4.0 & 13.5 & 1.3 \\
\hline $7 / 27 / 86$ & 29.0 & 0.8 & 0.0 & 0.8 \\
\hline $7 / 29 / 86$ & 26.0 & 0.4 & 2.0 & 0.8 \\
\hline $8 / 02 / 86^{\dagger}$ & 18.0 & 1.0 & 0.0 & 0.0 \\
\hline $8 / 08 / 86^{t}$ & 24.0 & 1.5 & 5.5 & 0.5 \\
\hline $8 / 18 / 86$ & 17.5 & 0.0 & 0.5 & 0.0 \\
\hline $11 / 08 / 86$ & 38.0 & 0.0 & 0.0 & 2.5 \\
\hline $11 / 21 / 86$ & 51.0 & 10.2 & 8.0 & 12.0 \\
\hline $\begin{array}{l}\text { TOTALS: } \\
+\end{array}$ & & 76.0 & 60.5 & 77.5 \\
\hline
\end{tabular}


precipitation rather than the intensity. As a result, runoff predictions are obscured in storms with small rainfall amounts but have high enough intensity to generate runoff. Failure to predict runoff in these events, especially if they occur close to the time of fertilizer or pesticide application, could seriously underestimate edge-of-field losses of agrichemicals. As was seen in this study, even small runoff events (June 24, 1985) can transport large amounts of soluble pesticides if they occur close to the time of application. Hall (1974) stated that 87 to 93 percent of the total pesticide loss can occur in the first five storms occurring after application.

Comparing the performance of the runoff prediction methods in excessive rate storms, the breakpoint intensity method proved to predict runoff better than the curve number method. On large excessive rate storms, (7/13/86 and $8 / 8 / 86)$, major differences in runoff volumes were observed between the breakpoint intensity method and the curve number method in the conventional tillage treatment (Table 13). Runoff predictions for the conventional treatment, using the curve number method, were less than observed on 7 out of the 8 excessive rate storms. On four of the eight events no runoff was predicted at all and on 2 of the events less than $1.0 \mathrm{~mm}$ of runoff was predicted. It is critical that runoff predictions for excessive rate storms are accurate because most of the soil movement and sediment-adsorbed nitrogen losses are associated with these storms. 
In most cases, the hydrology component predicted runoff reasonably close to observed values. In the conventional tillage system, the breakpoint intensity method performed well for small, large, and excessive rate storms. However, the RMS Error and the Reliability Index were relatively high indicating that there was a considerably amount of variability in the predictions. The linear regression line of the curve number method showed an acceptable correlation to the observed values but the problems associated with the excessive rate storms severely limit the utility of this method for estimating overall edge-of-field losses.

For the no-till treatments the curve number predicting runoff reasonably well. The breakpoint intensity method grossly underpredicted runoff for the two largest storms and the results of the statistical tests were the worst for all four simulations. The soil property dynamics in the no-till system are least understood (Blevins, 1985). Further adjustments to soil property parameters beyond the recommended range of values would be required to greatly improve the runoff predictions in this treatment. 


\section{CONCLUSIONS}

1) Surface rye crop residue can significantly reduce runoff and erosion losses from silage corn fields.

2) Reduced tillage without a winter cover crop does not significantly improve overland runoff and erosion control.

3) The additional surface residue provided by a winter cover crop has no significant effect on runoff and erosion losses following spring tillage with a conventional moldboard plow.

4) Tillage method and residue cover had no significant effect on atrazine and nitrogen concentrations in runoff. However, total losses were substantially reduced by reducing the amount of runoff and the occurrence of runoff.

5) Excessive rate storms generated 57 to 62 percent of the total runoff volume and 70 to 77 percent of the total soil loss that occurred during the study period.

6) Substantial calibration of the hydrology component of the CREAMS computer model was required in order to achieve close agreement between predicted and observed runoff values.

7) The Curve number method, which relies on daily rainfall records for runoff prediction, does not accurately simulate the occurrence and the magnitude of runoff on exccesive rate storms. 
8) The breakpoint intensity method performed well for the small, intense storms but generally underestimated runoff volume occurring from conservation tilled fields during large rainfall events.

9) In general, the CREAMS computer model requires more evaluation with observed field data before it can be considered a cost-effective method of estimating the effects of alternate management systems on nonpoint source pollution. 


\section{RECOMMENDATIONS FOR FURTHER RESEARCH}

1) Quantify nitrogen and atrazine leaching losses and perform a mass balance analysis of nitrogen and atrazine movement from silage corn.

2) Continue monitoring overland flow from the field plots to increase the data base.

3) Compare observed soil loss values to predicted soil loss values obtained from the erosion component of CREAMS.

4) Alter the CREAMS model to include the monthly probabilities of intense rain storms to adjust the curve number value when estimating runoff volume.

5) Obtain accurate measurements of surface infiltration throughout the year.

6) Expand monitoring to the dormant season to generate annual loss estimates of sediment and agrichemicals.

7) Eliminate chisel and notill plots without rye cover from the field study so that replicates of the remaining treatments can be increased. 


\section{LITERATURE CITED}

Armstrong, D.E., F.W. Lee, P.D. Uttormark, D.R. Keeney and R.F. Harris. 1974. Pollution of the Great Lakes by nutrients from agricultural land. Vol. 1. International Reference Group on Great Lakes Pollution from Land Use Activities. Category A6 Ann Arbor, MI.

Association of State and Interstate Water Pollution Control Administrators. 1984. Analysis of the states' response to ASIWPCA nonpoint source pollution survey. Washington, D.C.

Baker, G.W. and H.P. Johnson. 1979. The effects of tillage system on pesticides in runoff from small watersheds. Trans. ASAE 22:554-559.

Bailey, G.W., R.R. Swank, Jr. and H.P. Nicholson. 1974. Predicting pesticide runoff from agricultural land: A conceptual model. J. Environ. Qual 3:95-102.

Baker, J.L. and J.M. Laflen. 1982. Effects of corn residue and fertilizer management on soluble nutrient runoff losses. Trans ASAE. $24: 344-347$.

Barisas, S.G., J.L. Baker, H.P. Johnson and J.M. Laflen. 1978. Effect of tillage systems on runoff losses of nutrients: A rainfall simulation study. Trans. ASAE. 21:643-648.

Blevins, R.L., W.W. Frye and M.S. Smith. 1985. The effects of conservation tillage on soil properties. In: A systems approach to conservation tillage. F.M. D'Itri (ed.). Lewis Publishers, Inc. Chelsea, MI.

Brakensiek, D.L., H.B. Osborn and W.J. Rawls. 1979. Field manual for research in agricultural hydrology. USDA-SEA. Agr. Handb. 224. Washington, D.C.

Burwell, R.E. and L.A. Kramer. 1983. Long-term annual runoff and soil loss from conventional and conservation tillage. J. Soil and Water Cons. 32:231-236.

Chesters, G. and L. Schierow. 1985. A primer on nonpoint pollution. J. Soil and Wat. Conserv. 40(1):9-13.

Chow, Ven Te. 1964. Statistical and probability analysis of hydrologic data. In: Handbook of applied hydrology, Ven Te Chow, (ed.). McGraw-Hill Book Company, New York, NY, Chapter 8 .

Clark, E.H. II. 1983. Statement on nonpoint pollution presented before the House Subcommittee on Water Resources - November 16, 1983. The Conservation Foundation, Washington, D.C. 11 pp. 
Cohen, S.Z., S.M. Creeger, R.F. Carsel and C.G. Enfield. 1984. Potential pesticide contamination of groundwater from agricultural uses. In: Treatment and Disposal of Pesticide Wastes. R.F. Krugar and J.N. Sieber (eds.) ACS Sym. Series No. 259, American Chemical Association, Washington, D.C.

Colbert, F.O., V.V. Holk and A.P. Appleby. 1975. Sorption of atrazine, terbutryu, and GS-14254 on natural and lime-amended soils. Weed Sci. 23:390-395.

Danie1, Wayne W. 1978. Applied Nonparametric Statistics. Houghton Mifflin Company, Boston. p. 225-233.

DeNoyelles, F., W.D. Kettle and D.E. Sinn. 1982. The responses of plankton communities in experimental ponds to atrazine, the most heavily used pesticide in the United States. Ecology 63(5): 1285-1293.

Duda, A.M. 1985. Environmental and economic damage causes by sediment agricultural nonpoint sources. Water Res. Bull. 21(2):225-232.

Eastin, E.F. 1978. Total nitrogen determination for plant material containing nitrate. Analytical Biochemistry. 85:591-594.

Frink, C.R. 1967. Nutrient budget: Rational analysis of eutrophication in a Connecticut lake. Environ. Sci. Technol. $1: 425-428$.

Green, W.A. and G.A. Ampt. 1911. Studies on soil physics. 1. The flow of air and water through soils. J. Agric. Sci. 4:1-24.

Greer, J.D. 1971. Effect of excessive rate rainstorms on erosion. J. Soil and Water Cons. 26:196-197.

Ha11, J.K., M. Paulus and E.R. Higgins. 1972. Losses of atrazine in runoff water and soil sediments. J. of Environ. Qual. $1(2): 172-176$.

Ha11, J.K. 1974. Erosional losses of s-triazine herbicides. J. Environ. Qual. 3:174-180.

Harlin, M.M. and B. Thorne-Mi1ler. 1981. Nutrient enrichment of seagrass beds in Rhode Island coastal lagoons. Marine Biology $65: 221-229$.

Helling, C.S. 1970. Movement of s-triazine herbicides in soils. Residue Rev. 32:311-353.

Henriksen, A. and A.R. Selmer-01sen. 1970. Automatic methods for determining nitrate and nitrite in water and soil extracts. Analyst. 95:514-518. 
Hershfield, D.M. 1961. Rainfall frequency atlas of the United States. Technical Paper No. 40. Weather Bureau, U.S. Dept. Comm., Washington, D.C.

Johnson, H.P., J.L. Baker, W.D. Shrader and J.M. Laflen. 1979. Tillage system effects on sediment and nutrients in runoff from sma11 watersheds. Trans. ASAE 22:1,110-1,114.

Kanwar, R.S., J.L. Baker and J.M. Laflen. 1985. Nitrate movement through the soil profile in relation to tillage system and fertilizer application method. Trans. ASAE 28, p. 1802-1807.

Kaufman, D.D. and P.C. Kearney. 1970. Microbial degradation of triazine herbicides. Res. Dev. 32:235-266.

Keaney, D.R. 1973. The nitrogen cycle in sediment-water systems. J. Environ. Qual. 2:15-29.

Kenimer, A.L., S. Mostaghimi, R.W. Young, T.A. Dillaha and V.O. Shanholtz. 1986. Effects of residue cover on pesticide losses from conventional and no-tillage systems. ASAE Paper No. 86-2541.

Knise1, W.G. ed. 1980. CREAMS: A field-scale model for chemicals, runoff and erosion from agricultural management systems.

USDA-SEA. Conserv. Res. Rep. No. 26, 643 pp.

Knisel, W.G., G.R. Foster and R.A. Leonard. 1983. CREAMS: A system for evaluating management practices. In: F.W. Schaller and G.W. Bailey (ed.). Agricultural Management and Water Quality. Iowa State University Press.

Knise1, W.G., D.C. Moffet and T.A. Dumper. 1985. Representing seasona1ly frozen soil with the CREAMS model. Trans. ASAE. 28(5): $1487-1493$.

Knisle, E. 1970. The triazine herbicides, the history of development. Residue Rev. 32:1-8.

Kramer, L.A. 1984. Seasonal runoff and soil loss from conventional and conservatin tilled corn. ASAE Paper No. 84-2554.

Laflen, J.M. and T.S. Colvin. 1981. Effect of crop residue on soil loss from continuous row cropping. Trans. ASAE. 24(3):605-609.

Leggett, R. and L. Williams. 1981. A reliability index for models. Ecol. Modeling. 13:303-313.

Lemos, P. and Lutz, J.F. 1958. Soil crusting and some factors affecting it. Soil Sci. Soc. Am. Proc. 21:261-266.

Lindstrom, M.J., S.C. Gupta, C.A. Onstad, W.B. Larson and R.F. Holt. 1979. Tillage and crop residue effects on soil erosion in the corn belt. J. Soil and Water Cons. 34:80-82. 
Lindstrom, M.J., W.B. Voorhees and G.W. Randall. 1981. Long-term tillage effects on inferrow runoff and infiltration. Soil Sci. Soc. Am. J. 45:945-948.

Lindstrom, M.J. and C.A. Onstad. 1983. Tillage systems influence on soil physical parameters and infiltration after planting. J. Soil and Water Cons. 39:149-152.

Mannering, J.V., L.D. Meyer and C.B. Johnson. 1966. Infiltration and erosion as affected by minimum tillage for corn. Soil Sci. Soc. Am. Proc. $27: 84-86$.

Massey, H.F. and M.L. Jackson. 1952. Selective erosion of soil fertility constituents. Soil Sci. Soc. Am. Proc. 16:353-356.

McDowe11, L.L. and K.C. McGregor. 1980. Nitrogen and phophorus losses in runoff from no-till soybeans. Trans. ASAE. 23:643-648.

McDowe11, L.L. and K.C. McGregor. 1984. Plant nutrient losses in runoff from conservation tillage corn. Soil and Tillage Research. 4:79-91.

McGregor, K.C. 1978. C factors for no-till and conventional-till soybeans from plot data. Trans. ASAE. 21:1119-1222.

McGregor, K.C. and J.D. Greer. 1982. Erosion control with no-till and reduced till corn for silage and corn. Trans. ASAE. 25:154-157.

Mockus, V. 1964. Estimates of direct runoff from storm rainfall. In Hydrology, Section 4, SCS Nat'1 Engineering Handbook. USDA, Washington, D.C. pp. 10.1-10.13.

Moldenhauer, W.C., G.W. Langdale, W. Frye, D.E. McCool, R.I. Papendick, D.E. Smika, W. Fryrear. 1983. Conservation tillage for erosion control. J. Soil and Water Cons. 38:144-151.

National Agricultural Chemical Association. 1985. Health Guidance Levels for Agricultural Chemicals in Groundwater.

National Research Council. 1978. Nitrates: An environmental assessment. Nat1. Acad. Sci., Washington, D.C.

National Research Institute. 1977. Pesticides and the environment.

Neibling, W.H. and G.R. Foster. 1977. Estimating deposition and sediment yield from overland flow processes. In: Proceedings International Symposium on Urban Hydrology, Hydraulics and Sediment Control. University of Kentucky, Lexington, Kentucky.

Pimenta1, D. 1971. Ecological effects of pesticides on non-target species. Executive Office of the President Office of Science and Technology, Washington, D.C. 
Quansah, C. 1983. Rate of soil detachment by overland flow, with and without rain and its relation with discharge, slope steepness and soil type. In: Soil Erosion and Conservation. S.A. E1-Swaify, W.C. Moldenhaur and Andrew Lo (ed.). Soil Conservation Society of America. Ankey, Iowa.

Reckhow, K.H. and Chapra, S.C. 1983. Confirmation of water quality models. Ecol. Modeling 20:113-133.

Reese, L.E., R.0. Hegg and R.E. Gartt. 1982. Runoff water quality from dairy pastures in the Piedmont region. Trans. ASAE. $25(3): 697-701$.

Ritter, W.F. 1986. Nitrate leaching under irrigation: A review. ASAE Paper No. 86-2601.

Roeth, R.W., T.L. Lavy and O.C. Burnside. 1969. Atrazine degradation in two soil profiles. Weed Sci. 17(2):202-205.

Romkens, M.J., D.W. Nelson and J.V. Mannering. 1973. Nitrogen and phosphorus composition of surface runoff as affected by tillage method. J. of Environ. Qual. 2(2):292-295.

Rudra, R.P., W.T. Dickinson and G.J. Wa11. 1985. Application of the CREAMS model in southern Ontario conditions. Trans. ASAE. 28(4): $1233-1240$.

Ryther, J.H. and W.M. Dunstan. 1971. Nitrogen phosphorous and eutrophication in the coastal marine environment. Science $171: 1008-1013$.

Schwab, G.0., R. Frevert, T.W. Edminster, and R.K. Barnes. 1981 . Soil and Water Conservation Engineering. John Wiley and Sons. New York, NY.

Shoemaker, C.A. and M.D. Harris. 1979. The effectiveness of SWCP's in comparison with other methods for reducing pesticide pollution. In: Effectiveness of Soil and Water Conservation Practices for Pollution Control. D.A. Haith and R.C. Loehr (eds.). EPA $600 / 3-79-106$.

Siemens, J.C. and W.R. Oschwald. 1976. Erosion control for corn tillage systems costs. Trans. ASAE. 19:69-72.

Sirons, G.J., R. Frank and T. Sawyer. 1973. Residues of atrazine, cynazine and their phytotoxic metabolites in a clay loam soil. J. Agric. Food Chem. 21:1016-1020.

Sloneker, L.L. and W.C. Moldenhauer. 1977. Measuring the amounts of crop residue remaining after tillage. J. Soil and Water Cons. 32:231-236. 
Smith, A.E. 1982. Herbicides and the soil environment in Canada. Can. J. of Soil Sci. 62(3):433-460.

Smith, G.E., F.D. Whitaker and H.G. Heinman. 1974. Losses of fertilizers and pesticides from claypan soils. Environmental Protection Series. Office of Research and Development. U.S. EPA, Washington, D.C.

Smith, R.E. and J.Y. Parlange. 1978. A parameter-efficient hydrologic infiltration model. Water Res. 14(3):533-538.

Smolen, M.D. 1981. Nutrient runoff from agricultural and non-agricultural watersheds. Trans. ASAE 21:981-987.

Soil Conservation Society of America. 1982. Resource conservation golssary, Ankeny, IA.

Steenhuis, T.S. and M.F. Walter. 1979. Definitions and qualitative evaluation of soil and water conservation practices. In: Effectiveness of Soil and Water Control Practices for Pollution Control. D.A. Haith and R.C. Loehr (eds.) EPA-600/3-79-106.

Stoltenberg, N.L. and J.L. White. 1953. Selective losses of plant nutrients by erosion. Soil Sci. Soc. Am. Proc. 17:406-410.

Thomann, R.V. 1982. Verification of water quality models. J. Env. Eng. Div. ASCE, 108(EE5).

Timmons, D.R., R.E. Burwell and R.F.Holt. 1968. Loss of crop nutrients through runoff. Minn. Sci. 24(4):16-18.

Timmons, D.R., R.F. Holt and J.J. Latterel1. 1970. Leaching of crop residues as a source of nutrients in surface water. Wat. Res. Bul. 6(5): 1367-1375.

Triplett, G.B. Jr., B.J. Conner and W.M. Edwards. 1978. Transport of atrazine and simazine in runoff from conventional and no till corn. J. of Environ. Qua1. 7(1):77-84.

U.S. Department of Agriculture. 1981. Soil and Water Resources Conservation Act: 1980 Appraisal, part 1: Soil, water and related resources in the United States: Status, condition and trends. Washington, D.C.

U.S. Dept. of Commerce. 1951-1973. Climatologica1 Summary. Kingston, RI. NOAA. Asheville, N.C.

U.S. Environmental Protection Agency. 1976. Quality criteria for water. EPA Report No. 440/9-76-023. Washington, D.C. 
U.S. Environmental Protection Agency. 1978. National water quality inventory: 1977 report to Congress. EPA Report No. 44/2-84-006. Washington, D.C.

U.S. Environmental Protection Agency. 1979. Methods for chemical analysis of water and waste. EPA 600-4-79-020. Environmental Monitoring and Laboratory, Cincinnati, Ohio.

U.S. Soil Conservation Service. 1972. National Engineering Handbook, Hydrology, Section 4 and U.S. Dept. Agr. ARS 41-172.

U.S. Soil Conservation Service. 1981. Rhode Island Soil Survey.

Vigon, B.W. 1985. The status of nonpoint source pollution: its nature, extent and control. Water Res. Bull. 21(2), p. 179-184.

Wauchope, R.D. 1978. The pesticide content of surface water draining from agricultural fields - a review. J. Environ. Qual. $7: 459-472$.

Wendt, R.C.and R.E. Burwel1. 1985. Runoff and soil losses for conventional, reduced, and no-till corn. J. Soil and Water Cons. $40(5): 450-455$.

White, A.W., A.P. Barnett, B.G. Wright and J.H. Holladay. 1967 . Atrazine losses from fallow land caused by runoff and erosion. Environ. Sci. technol. 1:740-744.

Williams, J.R. and W.V. LaSeur. 1976. Water yield model using SCS curve numbers. J. Hydraul. Div., ASCE. 102(HY9):1241-53.

Wischmeier, W.H. and D.D. Smith. 1978. Predicting rainfall erosion losses - a guide to conservation planning. USDA Agr. Handb. 537. Washington, D.C.

Wu, T.L., N.J. Mick and B. Fox. 1977. Runoff studies of the agricultural herbicides alachlor and atrazine from Rhode River watersheds during 1976 growing season. In: Watershed Research in Eastern North American. D.L. Correll (ed.) Smithsonian Press, Washington, D.C. p. 707-726.

Wu, T.L. 1980. Dissipation of the herbicides atrazine and alachlor in a Maryland corn field. J. Environ. Qual. 9(3):459-465. 